\title{
Disease-, region- and cell type specific diversity of a-synuclein carboxy terminal truncations in synucleinopathies
}

\author{
Ethan W. Hass ${ }^{1,2+}$, Zachary A. Sorrentino ${ }^{1,2+}$, Yuxing Xia ${ }^{1,2}$, Grace M. Lloyd ${ }^{1,2}$, John Q. Trojanowski ${ }^{3}$, \\ Stefan Prokop ${ }^{2,4,5}$ and Benoit I. Giasson 1,2,4*(B)
}

\begin{abstract}
Synucleinopathies, including Parkinson's disease (PD), Lewy body dementia (LBD), Alzheimer's disease with amygdala restricted Lewy bodies (AD/ALB), and multiple system atrophy (MSA) comprise a spectrum of neurodegenerative disorders characterized by the presence of distinct pathological a-synuclein (aSyn) inclusions. Experimental and pathological studies support the notion that aSyn aggregates contribute to cellular demise and dysfunction with disease progression associated with a prion-like spread of aSyn aggregates via conformational templating. The initiating event(s) and factors that contribute to diverse forms of synucleinopathies remain poorly understood. A major post-translational modification of aSyn associated with pathological inclusions is a diverse array of specific truncations within the carboxy terminal region. While these modifications have been shown experimentally to induce and promote aSyn aggregation, little is known about their disease-, region- and cell type specific distribution. To this end, we generated a series of monoclonal antibodies specific to neo-epitopes in aSyn truncated after residues 103, 115, 119, 122,125 , and 129. Immunocytochemical investigations using these new tools revealed striking differences in the aSyn truncation pattern between different synucleinopathies, brain regions and specific cellular populations. In LBD, neuronal inclusions in the substantia nigra and amygdala were positive for aSyn cleaved after residues 103, 119, 122, and 125 , but not 115. In contrast, in the same patients' brain aSyn cleaved at residue 115, as well as 103, 119 and 122 were abundant in the dorsal motor nucleus of the vagus. In patients with AD/ALB, these modifications were only weakly or not detected in amygdala aSyn inclusions. aSyn truncated at residues 103, 115, 119, and 125 was readily present in MSA glial cytoplasmic inclusions, but 122 cleaved aSyn was only weakly or not present. Conversely, MSA neuronal pathology in the pontine nuclei was strongly reactive to the aSyn $x-122$ neo-epitope but did not display any reactivity for aSyn 103 cleavage. These studies demonstrate significant disease-, region- and cell type specific differences in carboxy terminal aSyn processing associated with pathological inclusions that likely contributes to their distinct strain-like prion properties and promotes the diversity displayed in the degrees of these insidious diseases.
\end{abstract}

Keywords: Carboxy, Inclusions, Lewy body dementia, Multiple system atrophy, a-synuclein, Truncation

*Correspondence: bgiasson@ufl.edu

†Ethan W. Hass and Zachary A. Sorrentino: These authors contributed equally

1 Department of Neuroscience, College of Medicine, University of Florida, BMS J483/CTRND, 1275 Center Drive, Gainesville, FL 32610, USA

Full list of author information is available at the end of the article

\section{Background}

Parkinson's disease (PD), Lewy body dementia (LBD) and multiple system atrophy (MSA) are characterized by the progressive accumulation of brain intracytoplasmic inclusions comprised of the protein $\alpha$-synuclein $(\alpha \operatorname{Syn})$ and are therefore collectively termed $\alpha$-synucleinopathies $[11,21-23,66]$. The definite role for $\alpha$ Syn in the etiology original author(s) and the source, provide a link to the Creative Commons licence, and indicate if changes were made. The images or other third party material in this article are included in the article's Creative Commons licence, unless indicated otherwise in a credit line to the material. If material is not included in the article's Creative Commons licence and your intended use is not permitted by statutory regulation or exceeds the permitted use, you will need to obtain permission directly from the copyright holder. To view a copy of this licence, visit http://creativecommons.org/licenses/by/4.0/. The Creative Commons Public Domain Dedication waiver (http://creativeco mmons.org/publicdomain/zero/1.0/) applies to the data made available in this article, unless otherwise stated in a credit line to the data. 
of these diseases was established by the discovery of missense mutations or duplication/triplication of the $\alpha$ Syn gene (SCNA) resulting in autosomal-dominant earlyonset PD or LBD [2, 10, 16, 34, 36, 37, 46, 49, 51, 56, 68]. Furthermore, numerous in vitro and animal experimental findings, as well as postmortem human studies, support the notion that the aberrant aggregation of $\alpha$ Syn and formation of pathological inclusions can spread throughout the CNS by a prion-like conformational templating mechanism that parallels the insidious nature of these human diseases $[8,27,64]$.

The biological mechanisms involved in initiating and promoting the spread of $\alpha$ Syn inclusion pathology that can present with "prion strain-like" properties are still highly debated $[8,27,64]$. While $\alpha$ Syn alterations due to genetic mutations are rare, $\alpha$ Syn species truncated at the carboxy terminus invariantly accumulate to comprise $\sim 20 \%$ of $\alpha$ Syn within pathological inclusions [1, 3, $9,33,39,44,57]$. Mechanistically, carboxy truncations of $\alpha$ Syn promote both its aggregation and toxicity $[57,60]$. Furthermore, the notion that specific $\alpha$ Syn carboxy truncations might be important in disease pathogenesis is underscored by a report that patients with appendectomy are less likely to develop PD, while selective carboxy truncated forms of $\alpha$ Syn can preferentially be generated in the vermiform appendix [35]. The presence of these various forms of truncated $\alpha$ Syn have been identified using mass spectrometry techniques, as well as with antibodies detecting neo-epitopes specific for truncated forms of $\alpha$ Syn (reviewed in [57]). Furthermore, using antibodies targeting the middle region of $\alpha$ Syn, or different amino acid stretches within its carboxy region, we were able to highlight that various forms of $\alpha$ Syn pathology had been underappreciated likely due to modification within this region $[25,58]$. However, the investigation of the presence of specific carboxy truncated forms of $\alpha$ Syn at the cellular level can only be performed by immunostaining with antibodies that exclusively react with the precise carboxy truncated forms of $\alpha$ Syn, as this cannot be readily achieved with biochemical methods. Only a limited number of studies have investigated the presence and properties of unique carboxy truncated forms of $\alpha$ Syn within human pathological inclusions due to the limited availability of antibodies specific for these modifications. Previous studies with carboxy truncated specific antibodies have shown that $\alpha$ Syn cleaved after residue 119 is detected in MSA glial cytoplasmic inclusions (GCIs) and Lewy pathology in PD, LBD and incidental Lewy body (LB) disease $[1,38,50]$, while reactivity to $\alpha$ Syn cleaved at residues 103 and 122 was detected in Lewy pathology [14, 69]. These previous pathological assessments of human tissue were performed with rabbit antibodies to short peptides corresponding to carboxy truncated forms of $\alpha$ Syn at residues 103, 119 and 122 [1, 14, 38, 50, 69] and some of these antibodies were proprietarily generated by Elan Pharmaceuticals (South San Francisco, CA, USA) $[1,50]$ and are not currently available.

Given the growing evidence that carboxy truncated forms of $\alpha$ Syn can be involved in the etiology of synucleinopathies [57], herein, we generated and characterized a new series of monoclonal antibodies specific for six of the cleaved forms of $\alpha$ Syn. We use these antibodies to investigate the cellular, neuroanatomical, and disease specificity of these post-translationally modified forms of $\alpha$ Syn within various $\alpha$ Syn pathologies associated with human neurodegenerative diseases.

\section{Methods}

\section{Generation of new aSyn monoclonal antibodies}

Synthetic peptides, listed in Table 1, corresponding to different amino acid stretches within the carboxyl terminal region of $\alpha$ Syn were synthesized and purified by GenScript USA, Inc. (Piscataway, NJ). All peptides contained an added Cys residue at the amino terminus that allowed for conjugation to maleimide-activated mariculture keyhole limpet hemocynanin (mcKLH) (Thermo Scientific, Waltham, MA). The peptides conjugated to mcKLH were used to immunize female BALC/c mice (Jackson Laboratory, Bar Harbor, ME) as previously described [53]. All procedures were performed according to the $\mathrm{NIH}$ Guide for the Care and Use of Experimental Animals and were approved by the University of Florida Institutional Animal Care and Use Committee. The spleens from the immunized mice were harvested, and the white blood cells were fused with mouse myeloma cells (Sp2/O-Ag14; ATCC, Manassas, VA) as previously described [53]. Following selection with HAT supplement (Sigma Aldrich, St. Louis, MO), all hybridoma clones were initially screened for reactivity by enzyme-linked immunosorbent

Table 1 List of new antibodies described here

\begin{tabular}{llll}
\hline Antibody name & Immunization peptide & asyn residues & Isotype \\
\hline $2 G 5$ & CFVKKDQLGKN & $94-103$ & $\lg G 1$ \\
$1 \mathrm{~B} 1$ & CAGPQEGILED & $106-115$ & $\lg \mathrm{g} 1$ \\
$3 \mathrm{G} 11$ & CAGPQEGILED & $106-115$ & $\lg \mathrm{g} 2 \mathrm{~B}$ \\
$4 \mathrm{H} 11$ & CEGILEDMPVD & $110-119$ & $\lg \mathrm{g} 1$ \\
$6 \mathrm{G} 2$ & CLEDMPVDPDN & $113-122$ & $\lg \mathrm{g} 1$ \\
$10 \mathrm{~A} 4$ & CLEDMPVDPDN & $113-122$ & $\lg \mathrm{g} 1$ \\
$5 \mathrm{C} 1$ & CDMPVDPDNEAY & $115-125$ & $\lg \mathrm{g} 1$ \\
$2 \mathrm{~B} 1$ & CDMPVDPDNEAY & $115-125$ & $\lg \mathrm{g} 1$ \\
$2 \mathrm{G} 7$ & CPVDPDNEAYEMPS & $117-129$ & $\lg \mathrm{g} 1$ \\
\hline
\end{tabular}

Shown are the synthetic peptides used for mouse immunization and their corresponding residues localization in human aSyn. The isotype of each antibody is included 
assay (ELISA) using the respective peptides used for immunization. Specific monoclonal antibodies for each truncated form of $\alpha$ Syn were then identified by ELISA using recombinant full-length $\alpha$ Syn compared to each respective recombinant carboxy truncated form of $\alpha$ Syn. The specificities of each antibody were further confirmed by ELISA and immunoblotting with a series of recombinant carboxy truncated $\alpha$ Syn (see Figs. 1 and 2). Antibody isotypes (Table 1) were determined using a mouse monoclonal isotyping kit (Millipore Sigma, Burlington, MA).

\section{Other aSyn antibodies}

2H6, 3H11 and 94-3A10 are mouse monoclonal anti$\alpha$ Syn antibodies with the epitopes including residues $2-21,43-62$ and $130-140$, respectively $[12,13]$.

\section{Enzyme-linked immunosorbent assay (ELISA)}

96-well ELISA plates (Corning Life Sciences, Corning, $\mathrm{NY}$ ) were coated with $100 \mathrm{ng}$ peptide in $100 \mu \mathrm{L}$ phosphate buffered saline (PBS) per well using the peptide used for immunization (see Table 1). Wells were washed with PBS and blocked with PBS/5\% fetal bovine serum (FBS). Primary antibodies were added to blocking solution and incubated at room temperature. After PBS washes, plates were incubated with horseradish peroxidase-conjugated anti-mouse antibody (Jackson Immuno Research Labs, West Grove, PA) in 5\% FBS/PBS for an hour. Plates were washed with PBS and 3,3,5,5'-tetramethylbenzidine (TMB substrate, Thermo Fisher Scientific, Waltham, MA) was added to each well. The reactions were stopped by adding $0.5 \mathrm{M} \mathrm{HCl}$ and the optical density was measured at $450 \mathrm{~nm}$ with a plate reader.

\section{Immunohistochemistry of human brain tissue}

Formalin-fixed brain samples of patients with LBD, Alzheimer's disease with amygdala restricted Lewy bodies (AD/ALB), MSA and controls were provided by the University of Florida Neuromedicine Human Brain and Tissue Bank (UF HBTB) (see Table 1) following institutional regulations. Some of these cases were previously used for other studies [13, 25, 58]. A second set of tissue that was fixed in either formalin or $70 \%$ ethanol/150 mM $\mathrm{NaCl}$ was obtained from the Center for Neurodegenerative Disease Research (CNDR) tissue bank at the University of Pennsylvania (see Table 2) following institutional regulations. Postmortem diagnoses of LBD, MSA, AD neuropathological change and other changes were made according to current guidelines and criteria proposed by the National Institute of Aging-Alzheimer's Association

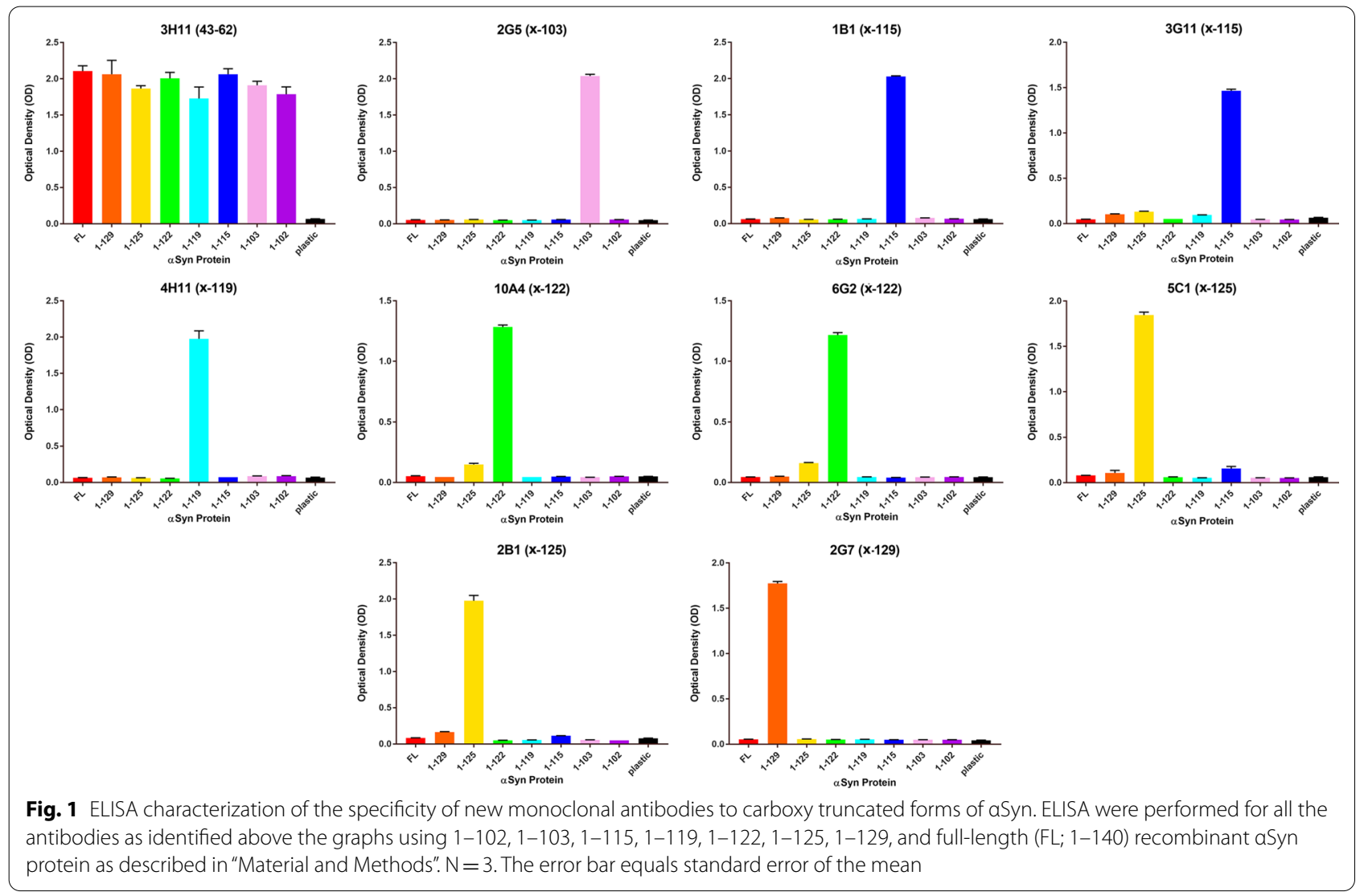




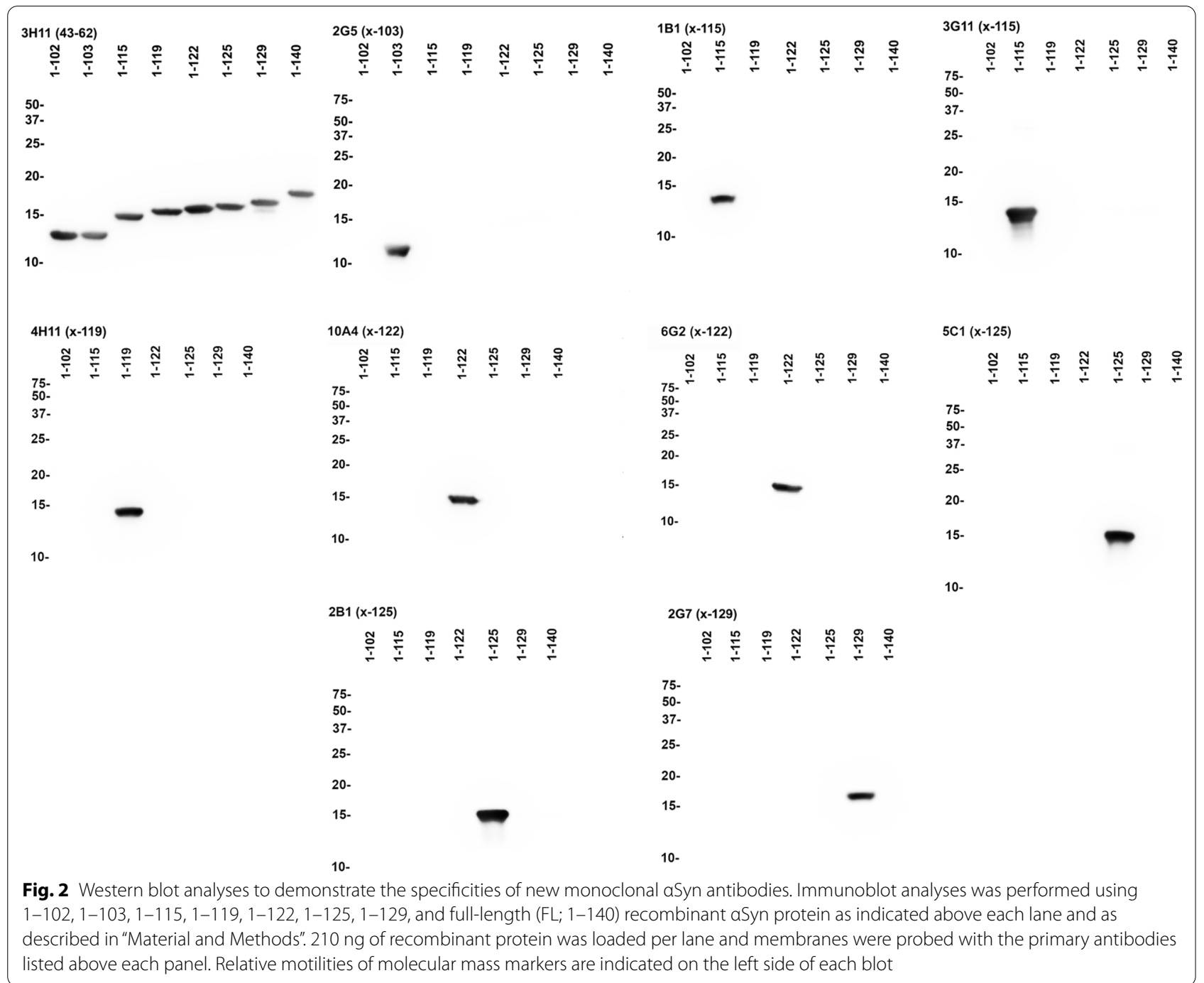

[28], the Dementia with Lewy Bodies Consortium [42], and the Neuropathology Working Group on MSA [20]. See Tables 2 and 3 for details on human cases used for this study.

For immunohistochemistry (IHC), paraffin-embedded tissue on slides were rehydrated in xylene and series of ethanol solutions $(100 \%, 90 \%$, and $70 \%)$. For antigen retrieval with most of the $\alpha$ Syn carboxy terminal specific antibodies, tissue sections were placed in a steam bath for $60 \mathrm{~min}$ in a solution of modified citrate buffer (Target Retrieval Solution Citrate pH 6; Agilent, Santa Clara, CA). After cooling down using tap water, sections were treated with $70 \%$ formic acid for $20 \mathrm{~min}$ at room temperature and extensively washed with water. For antibodies 94-3A10 and 4H11, tissue sections were treated with $70 \%$ formic acid for 20 min at room temperature and after extensive washing with water, placed in a steam bath for $60 \mathrm{~min}$ in a solution of modified citrate buffer (Target Retrieval Solution Citrate pH 6; Agilent, Santa Clara, CA). Endogenous peroxidases were quenched by submerging slides in PBS solutions with $1.5 \%$ hydrogen peroxide and $0.005 \%$ Triton-X-100. After washing, slides were blocked in 2\% FBS/0.1 M Tris, pH 7.6 and were incubated in primary antibody overnight at $4^{\circ} \mathrm{C}$. After washes with $0.1 \mathrm{M}$ Tris, $\mathrm{pH}$ 7.6, a mixture of biotinylated secondary antibody (Vector Laboratories; Burlingame, CA) and ImmPRESS polymer secondary antibody (Vector Laboratories; Burlingame, CA) were similarly diluted 
Table 2 Summary of cases form the University of Florida Neuromedicine Human Brain and Tissue Bank used in this study

\begin{tabular}{|c|c|c|c|c|c|c|c|c|c|}
\hline Case & Clinical diagnosis & $\begin{array}{l}\text { Primary pathological } \\
\text { diagnosis }\end{array}$ & $\begin{array}{l}\text { Secondary } \\
\text { pathological diagnosis }\end{array}$ & $\begin{array}{l}\text { Amyloid } \\
\text { score } \\
\text { (Thal) }\end{array}$ & Braak & CERAD & Gender & Age & PMI (hrs) \\
\hline Control 1 & Normal & AD low & & 1 & $\|$ & none & M & 88 & 4 \\
\hline Control 2 & Normal & PART & & 0 & $\|$ & none & $\mathrm{F}$ & 72 & 4 \\
\hline Control 3 & Normal & $\begin{array}{l}\text { No significant pathologi- } \\
\text { cal findings }\end{array}$ & & 0 & 0 & none & $\mathrm{F}$ & 55 & 12 \\
\hline Control 4 & $\begin{array}{l}\text { Progressive Myoclonic } \\
\text { Epilepsy (Unverricht- } \\
\text { Lundborg variant: } \\
\text { EPM1)* }\end{array}$ & $\begin{array}{l}\text { No significant pathologi- } \\
\text { cal findings }\end{array}$ & & 0 & 0 & 0 & M & 51 & 31 \\
\hline FTLD-1 & FTLD & FTLD-TDP43 & & 1 & 0 & none & $\mathrm{F}$ & 67 & 30 \\
\hline MSA-1 & MSA-C & MSA & & 0 & 0 & none & $\mathrm{F}$ & 67 & 4 \\
\hline MSA-2 & MSA-P & MSA & AD low & 1 & । & none & $\mathrm{F}$ & 60 & 6 \\
\hline MSA-3 & MSA-P & MSA & PART & 0 & $\|$ & none & M & 77 & 18 \\
\hline MSA-4 & MSA-C & MSA & AD low; CAA & 2 & । & sparse & M & 71 & 4 \\
\hline MSA-5 & MSA-C & MSA & AD intermediate & 2 & III & sparse & M & 59 & 4 \\
\hline MSA-6 & MSA-P/C & MSA & PART, CAA & 0 & । & none & $\mathrm{F}$ & 66 & 22 \\
\hline MSA-7 & MSA-P & MSA & & 0 & 0 & none & $F$ & 66 & 14 \\
\hline LBD-1 & DLB & LBD diffuse neocortical & $\mathrm{AD}$ intermediate; CAA & 3 & IV & moderate & M & 67 & 13 \\
\hline LBD-2 & DLB & LBD diffuse neocortical & $\begin{array}{l}\text { AD intermediate; CAA; } \\
\text { ARTAG }\end{array}$ & 3 & III & sparse & $\mathrm{F}$ & 67 & 4 \\
\hline LBD-3 & $A D$ & LBD diffuse neocortical & $\mathrm{AD}$ intermediate; CAA & 3 & IV & frequent & $\mathrm{F}$ & 81 & 15 \\
\hline LBD-4 & $A D$ & LBD diffuse neocortical & AD high; CAA & 3 & V & frequent & $F$ & 74 & 8 \\
\hline LBD-5 & $A D$ & LBD diffuse neocortical & AD high; CAA & 3 & $\mathrm{Vl}$ & frequent & M & 80 & 21 \\
\hline AD/ALB-1 & $A D$ & LBD limbic-transitional & AD intermediate; CAA & 2 & V & moderate & $F$ & 83 & 9 \\
\hline AD/ALB-2 & $A D$ & LBD amygdala & AD high; CAA & 3 & $\mathrm{Vl}$ & frequent & M & 64 & 3 \\
\hline AD/ALB-3 & $A D$ & LBD amygdala & AD high; CAA & 3 & $\mathrm{VI}$ & frequent & $F$ & 67 & 8 \\
\hline
\end{tabular}

Listed are the clinical and pathological diagnoses, the sex, age at death, amyloid score (Thal), Braak stage and CERAD ratings. $A D$ Alzheimer's disease, $A D / A L B$ AD with amygdala restricted Lewy bodies, ARTAG aging related tau astrogliopathy, CAA cerebral amyloid angiopathy, DLB dementia with Lewy body, FTLD frontotemporal lobar degeneration, LATE limbic-predominant age related TDP-43 encephalopathy, LBD Lewy body dementia, MSA-C multiple system atrophy with predominant cerebellar ataxia, MSA-P multiple system atrophy with predominant Parkinsonism, $P A R T$ primary age-related tauopathy, $P M I$ postmortem interval. ${ }^{*} C T S B$ mutation

Table 3 Summary of cases from the University of Pennsylvania Tissue Bank used in this study

\begin{tabular}{|c|c|c|c|c|c|c|c|c|}
\hline Case & Clinical diagnosis & Pathological diagnosis & $\begin{array}{l}\text { Amyloid } \\
\text { score (Thal) }\end{array}$ & Braak & CERAD & Gender & Age & PMI (hrs) \\
\hline MSA-8 & Spinocerebellar ataxia & MSA & 1 & $\|$ & sparse & Female & 76 & 12 \\
\hline MSA-9 & MSA-C & MSA & 0 & 0 & none & Male & 68 & 8 \\
\hline MSA-10 & MSA-C & MSA & 0 & $\|$ & none & Male & 72 & 9 \\
\hline LBD-6 & PD & LBD diffuse neocortical & 2 & III/IV & frequent & Female & 82 & 5 \\
\hline LBD-7 & $\mathrm{DLB}$ & LBD diffuse neocortical & 1 & $|/| \mid$ & none & Male & 68 & 15 \\
\hline LBD-8 & Corticobasal syndrome & LBD diffuse neocortical & 3 & $|/| \mid$ & moderate & Male & 83 & 20 \\
\hline
\end{tabular}

Listed are the clinical and pathological diagnoses, the sex, age at death, amyloid score (Thal), Braak stage and CERAD ratings. DLB dementia with Lewy body, LBD Lewy body dementia, MSA-C multiple system atrophy with predominant cerebellar ataxia, MSA-P multiple system atrophy with predominant Parkinsonism, $P D$ Parkinson's disease, $P M I$ postmortem interval

in block solution and applied to sections for $1 \mathrm{~h}$ at room temperature. An avidin-biotin complex (ABC) system (Vectastain ABC Elite kit; Vector Laboratories, Burlingame, $\mathrm{CA}$ ) was used to enhance detection of the immunocomplexes, which were visualized using the chromogen 3,3'-diaminobenzidine (DAB kit; KPL, Gaithersburg, MD). Tissue sections were counterstained with hematoxylin (Sigma Aldrich, St. 


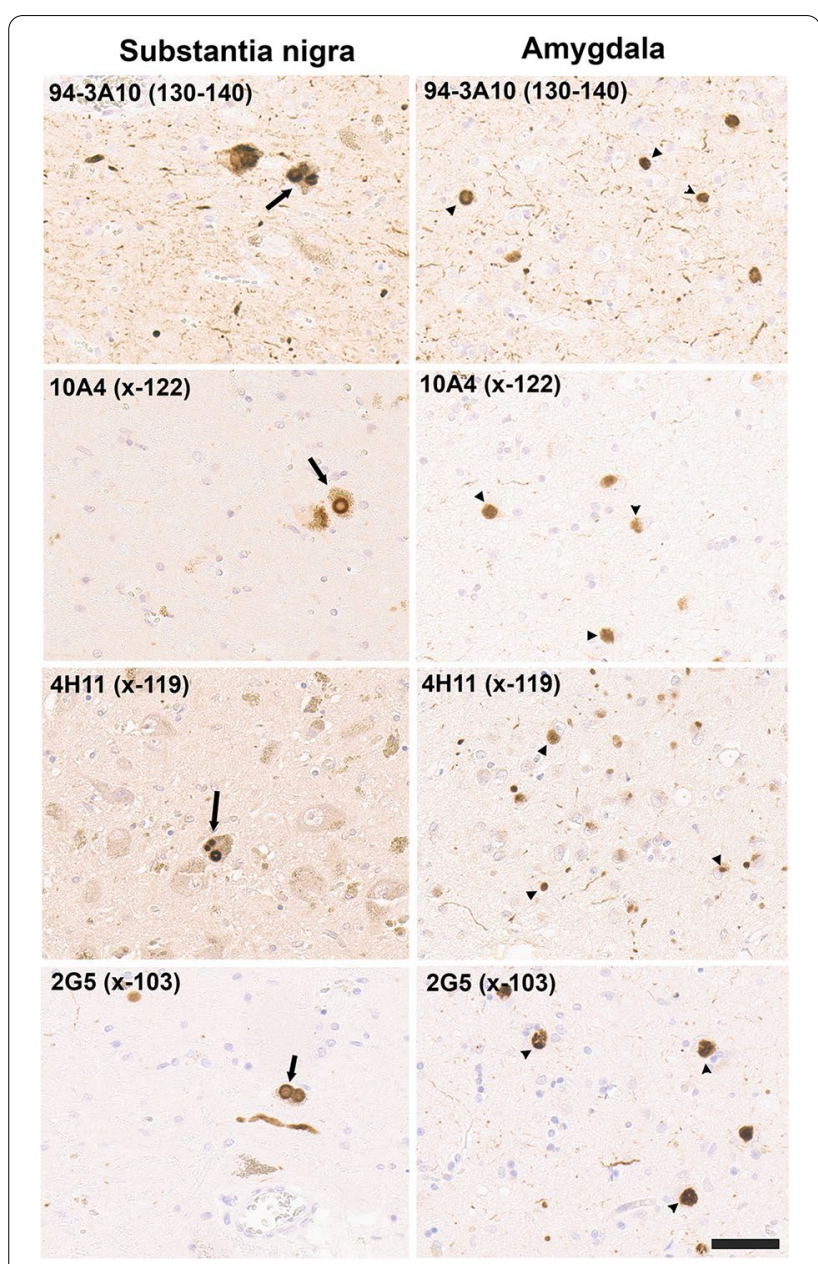

Fig. $3 \mathrm{HC}$ staining of the substantia nigra and amygdala in formalin fixed tissue sections from an LBD patient with antibodies to full length or carboxy truncated forms of aSyn. In the substantia nigra (left panels), antibody 94-3A10 that reacts with amino acid region 130-140 in aSyn and antibodies (10A4, 4H11, and 2G5) specific for carboxy truncated forms of aSyn strongly labeled classic LBs. In the amygdala (right panels), these antibodies also labeled cortical-type LBs and LNs. Tissue sections were stained with the aSyn antibodies indicated in the top left corner. Arrow depicts classical nigral LBs and arrowhead cortical-type LBs. All sections were counterstained with hematoxylin. Scale bar $=50 \mu \mathrm{m}$

Louis, MO). Slides were dehydrated in ethanol solutions $(70 \%, 90 \%$, and $100 \%)$ and xylene before they were covered with Cytoseal (Thermo Fisher Scientific, Waltham, MA). Slides were digitally scanned using an Aperio Slide Scanner AT2 instrument (40X magnification; Aperio Technologies Inc., Vista, CA).

\section{Semiquantitative assessment of staining intensity and quality for monoclonal antibodies}

Staining intensity and quality were assessed against the baseline of 94-3A10 staining. "Strong" indicates equal staining intensity and quality compared to baseline (best illustrated in Fig. 4 for antibodies 1B1, 10A4, 2G5 and $4 \mathrm{H} 11$ ), while "weak/none" represents absent or very faint staining compared to baseline (best illustrated in Fig. 5 for antibodies 4H11, 2G5 and 10A4). "Moderate" was assigned to staining quality and intensity in between these two extremes, as demonstrated in Fig. 11 for pontine neuronal inclusions in MSA (compared to our previously published data [25]). Assessment of staining intensity and quality was independently conducted by EWH, BIG and SP and the overall consensus score is represented in Table 4.

\section{Sequential biochemical fractionation of human nervous tissue}

Amygdala or temporal cortex adjacent to the amygdala from LBD patients and control without any Lewy pathology were used. Tissues were homogenized with $3 \mathrm{~mL}$ per gram of tissue with high salt (HS) buffer $(50 \mathrm{mM}$ Tris, pH 7.5, $750 \mathrm{mM} \mathrm{NaCl}, 20 \mathrm{mM} \mathrm{NaF}, 5 \mathrm{mM}$ EDTA) with a cocktail of protease inhibitors $(1 \mathrm{mM}$ phenylmethylsulfonyl fluoride and $1 \mathrm{mg} / \mathrm{ml}$ each of pepstatin, leupeptin, N-tosyl-L-phenylalanyl chloromethyl ketone, $\mathrm{N}$-tosyl-lysine chloromethyl ketone and soybean trypsin inhibitor). The tissue homogenates then underwent sedimentation at $100,000 \times \mathrm{g}$ for $30 \mathrm{~min}$ and the supernatants were removed and kept as the HS fraction. Pellets were re-extracted in $3 \mathrm{~mL}$ per gram of tissue with $\mathrm{HS}$ buffer with $1 \%$ Triton X-100 (HS/T buffer) and centrifuged at $100,000 \times \mathrm{g}$ for $30 \mathrm{~min}$. The supernatants were removed and kept as the HS/T fraction. The pellets were then homogenized in 3 volumes per gram of tissue with HS buffer/1\% Triton X-100 with $1 \mathrm{M}$ sucrose and centrifuged at $100,000 \times \mathrm{g}$ for $30 \mathrm{~min}$ to float the myelin, which was discarded. Pellets were homogenized in $2 \mathrm{~mL}$ per gram of tissue with radioimmunoprecipitation assay (RIPA) buffer (50 mM Tris, pH 8.0, $150 \mathrm{mM} \mathrm{NaCl,} 5 \mathrm{mM}$ EDTA, 1\% NP-40, 0.5\% sodium deoxycholate, 0.1\% SDS) plus protease inhibitors and centrifuged at $100,000 \times \mathrm{g}$ for $30 \mathrm{~min}$. Supernatants were removed and kept as the RIPA fraction. Pellets were then homogenized in $1 \mathrm{~mL}$ per gram of tissue with $2 \%$ SDS/4 M urea by probe sonication, and centrifuged at $100,000 \times \mathrm{g}$ for $30 \mathrm{~min}$ and supernatant was kept as the SDS/U fractions. Protein 
concentrations of all fractions were determined by BCA assay using bovine serum albumin (BSA; Pierce, Rockford, IL) as a standard. SDS sample buffer was added to the fractions which were incubated for $10 \mathrm{~min}$ at $100{ }^{\circ} \mathrm{C}$ (HS and HS/T fractions) or at room temperature (SDS/U fraction only). Equal amounts of protein were resolved by SDS-PAGE and analyzed by immunoblot.

\section{Recombinant synuclein proteins}

Full-length (1-140), 1-129, 1-125, 1-122, 1-119, 1-115, $1-103$ and 1-102 carboxy truncated human $\alpha$ Syn as well as full-length human $\beta$-synuclein ( $\beta$ Syn) and $\gamma$-synuclein $(\gamma$ Syn $)$ were expressed using the bacterial expression plasmid pRK172 in BL21 (DE3) E.coli (New England Biolabs Inc). Full-length and 1-129, 1-125, 1-122, 1-119, and $1-115$ human $\alpha$ Syn recombinant proteins and $\beta S y n$ and $\gamma$ Syn were purified using size exclusion chromatography followed by Mono Q anion exchange chromatography as previously described [60]. 1-103 and 1-102 carboxy truncated human $\alpha$ Syn were purified using size exclusion chromatography followed by Mono $\mathrm{S}$ anion exchange chromatography.

\section{Immunoblotting analyses}

Protein samples were resolved by SDS-PAGE on $15 \%$ SDS-polyacrylamide gels. The proteins were then electrophoretically transferred onto $0.2 \mu \mathrm{m}$ pore size nitrocellulose membranes (Bio-Rad, Hercules, CA) in carbonate transfer buffer $(10 \mathrm{mM} \mathrm{NaHCO}, 3 \mathrm{mM}$ $\mathrm{Na}_{2} \mathrm{CO}_{3}$, pH 9.9)[15] with $20 \%$ methanol running at constant current of $255 \mathrm{~mA}$ for $75 \mathrm{~min}$. Membranes were washed with Tris-buffered saline (TBS), blocked with 5\% milk/TBS and incubated overnight at $4{ }^{\circ} \mathrm{C}$ with primary antibodies. Following washing, blots were incubated with HRP conjugated goat anti-mouse antibody (Jackson Immuno Research Labs, West Grove, PA) diluted in 5\% milk/TBS for $1 \mathrm{~h}$. Following washing, the labeled protein bands were visualized by chemiluminescence using Western Lightning Plus ECL reagents (PerkinElmer Life Sciences, Waltham, MA) and with a GeneGnome XRQ imager (Syngene, Frederick, MD).

\section{Results \\ Generation and characterization of new mouse monoclonal antibodies specific for various carboxy truncated forms of human aSyn}

To generate a series of new monoclonal antibodies specific for truncated forms of $\alpha$ Syn, short synthetic peptides with amino acid sequences corresponding to human $\alpha$ Syn ending at residues $103,115,119,122,125$ or 129 (Table 1 ) were chemically conjugated to mcKLH and used as immunogens. This array of specific cleavage sites in human $\alpha$ Syn was selected based on previous evidence that they were associated with human pathology, occur during the process of cellular transmission or variably affect the propensity of $\alpha$ Syn to aggregate $[48,57,60]$. The hybridomas generated from the fusion of mouse spleen isolated lymphocytes with $\mathrm{Sp} 2 / \mathrm{O}-\mathrm{Ag} 14$ murine myeloma cells were first screened for antibody secretion by ELISA for reaction with the original peptides used for immunization. The positive antibodies were then screened by ELISA using plates coated with recombinant full-length human $\alpha$ Syn, compared to recombinant human $\alpha$ Syn proteins corresponding to the respective carboxy truncation of each antibody, selecting for antibodies against neo-epitopes that would only be present in the truncated proteins and not full-length proteins.

Monoclonal antibodies specific for each of these carboxy truncated forms of $\alpha$ Syn (Table 1) were obtained that were further validated by ELISA using the whole spectrum of recombinant carboxy truncated forms of $\alpha$ Syn (Fig. 1), as well as $\beta$ Syn and $\gamma$ Syn (Additional file 1 : Figure S1). These antibodies were very specific for these respective targeted modifications. For example, antibody

Table 4 Summary of aSyn pathologies staining with the series for monoclonal antibodies specific for carboxy cleaved aSyn species

\begin{tabular}{|c|c|c|c|c|c|c|}
\hline $\begin{array}{c}\alpha \text { Syn } \\
\text { cleavage } \\
\text { site }\end{array}$ & $\begin{array}{c}\text { Classical } \\
\text { LBs/SN } \\
\text { (LBD) }\end{array}$ & $\begin{array}{c}\text { Cortical LBs } \\
\text { and LNs/ } \\
\text { amygdala } \\
\text { (LBD) }\end{array}$ & $\begin{array}{c}\alpha \text { Syn } \\
\text { inclusions/ } \\
\text { DMV } \\
\text { (LBD) }\end{array}$ & $\begin{array}{c}\text { Cortical LBs } \\
\text { and } \\
\text { LNs/amygdala } \\
\text { (AD/ALB) }\end{array}$ & $\begin{array}{c}\text { GCls/cerebellum } \\
\text { and pons } \\
\text { (MSA) }\end{array}$ & $\begin{array}{c}\text { Neuronal } \\
\text { inclusions/pons } \\
\text { (MSA) }\end{array}$ \\
\hline $\mathrm{x}-103$ & strong & strong & strong & weak/none & strong & none \\
\hline $\mathrm{x}-115$ & weak/none & weak/none & strong & weak/none & strong & strong \\
\hline $\mathrm{x}-119$ & strong & strong & strong & weak/none & strong & strong \\
\hline $\mathrm{x}-122$ & strong & strong & strong & weak/none & weak/none & strong \\
\hline $\mathrm{x}-125^{*}$ & strong & strong & ND & ND & strong & moderate \\
\hline $\mathrm{x}-129$ & none & none & none & none & none & none \\
\hline
\end{tabular}

*based on staining in ethanol fixed tissue as the $\mathrm{x}-125$ neo-epitope is compromised by formalin fixation. $A D / A L B$ AD with amygdala restricted Lewy bodies, $D M V$ dorsal motor nucleus of the vagus, GCls glial cytoplasmic inclusions, LBs Lewy bodies, LBD Lewy body dementia, LNs Lewy neurites, MSA multiple system atrophy, SN substantia nigra, ND not determined 


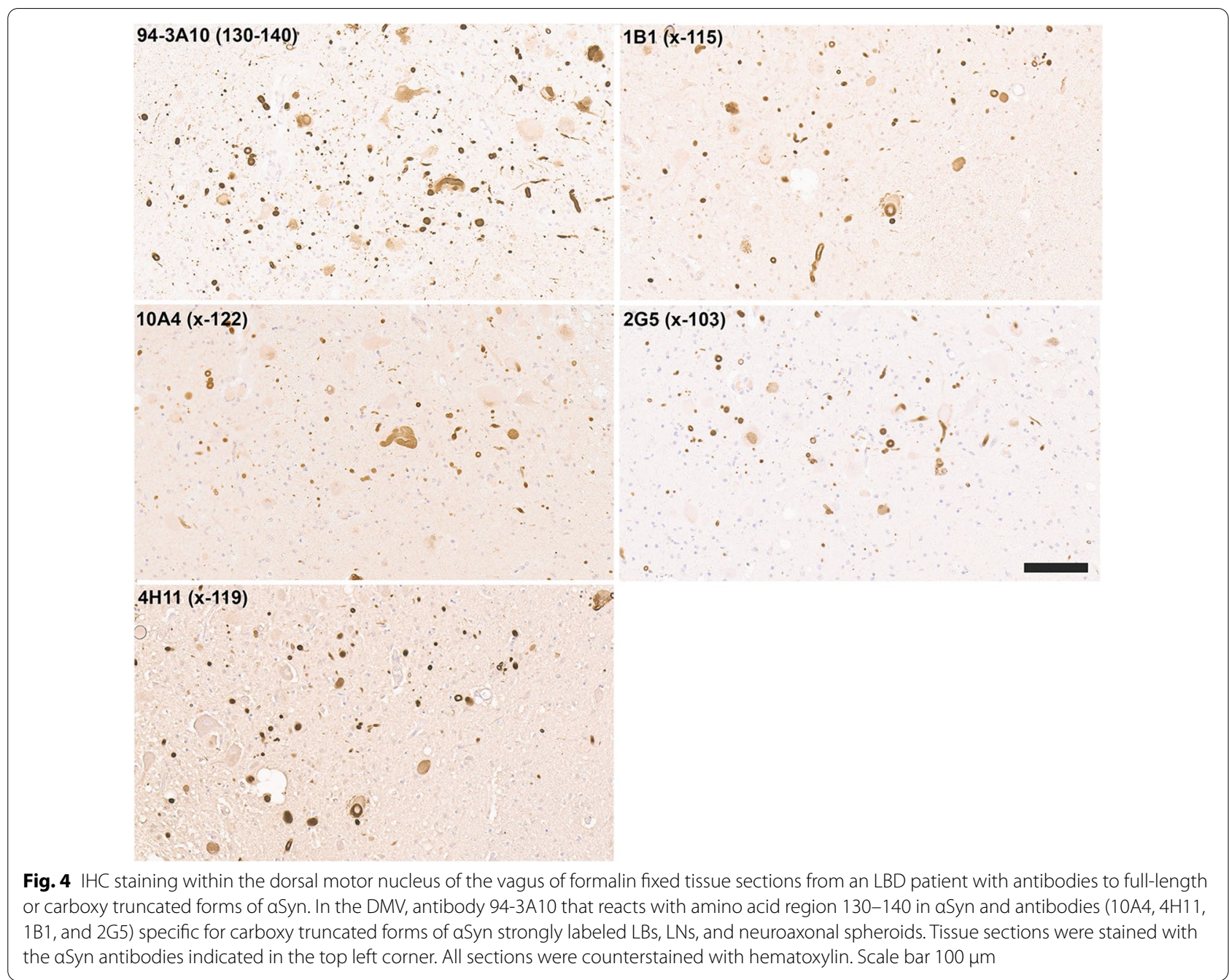

2 G5 was strongly reactive to $\alpha$ Syn $1-103$ but did not react with $\alpha$ Syn 1-102 (Fig. 1). We further validated the specificity of all these antibodies by immunoblotting (Fig. 2) and show that they demonstrate minimal cross-reactivity to other proteins in soluble extracts from human brain (Additional file 1: Figure S2).

\section{Labeling pattern of distinct inclusions in synucleinopathies with new monoclonal antibodies specific for carboxy truncated forms aSyn}

The new array of monoclonal antibodies specific to various specific forms of carboxy truncated $\alpha$ Syn was used to immunolabel a series of formalin fixed human cases with Lewy body pathology (Table 2). Compared to a $\alpha$ Syn antibody 94-3A10 that reacts with full-length $\alpha$ Syn, antibodies specific for $\alpha$ Syn truncated after residues 122, 119, and 103 extensively labeled classic Lewy bodies in the substantia nigra and cortical-type Lewy bodies and Lewy neurites as shown in the amygdala (Fig. 3). Antibodies specific for $\alpha$ Syn truncated after residues 129, 125, and 115 displayed little to no labeling of these pathologies (data not shown).

In the dorsal motor nucleus of the vagus (DMV), immunostaining for antibodies specific for $\alpha$ Syn truncated after residues 122, 119, and 103 also revealed strong staining for Lewy bodies and extensive neuroaxonal spheroids (Fig. 4). In contrast to inclusions in the amygdala and substantia nigra, these pathological inclusions were also highlighted with antibodies specific for $\alpha$ Syn truncated after residue 115 (Fig. 4). Antibodies specific for $\alpha$ Syn truncated after residues 129 and 125 displayed 


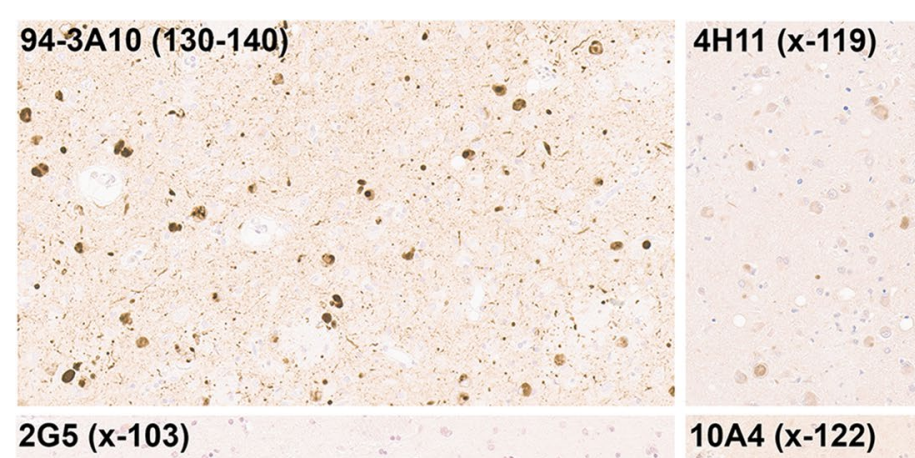

Fig. 5 IHC staining of amygdala formalin fixed tissue sections from an AD/ALB brain with antibodies specific for full-length or carboxy truncated forms of aSyn. In the amygdala of AD/ALB, antibody 94-3A10 that reacts with amino acid region 130-140 in aSyn strongly stained Lewy pathology, but antibodies (10A4, 4H11, and 2G5) specific for carboxy truncated forms of aSyn only weakly or did not stain these inclusions. Tissue sections were stained with the aSyn antibodies indicated in the top left corner. All sections were counterstained with hematoxylin. Scale bar $100 \mu \mathrm{m}$

little to no labeling of these pathologies in formalin fixed tissue sections (data not shown).

In $40-60 \%$ of patients with Alzheimer's disease (AD), Lewy body pathology can be found largely restricted to the amygdala and the closely associated limbic system $[24,45,65]$, referred to here as AD/ALB. Staining with our new antibodies for carboxy truncated forms of $\alpha$ Syn demonstrates strong labelling of these neuronal inclusions with antibody 94-3A10, but antibodies specific to $\alpha$ Syn truncated after residues 103 (2G5), 115 (1B1), 119 (4H11) and 122 (10A4) revealed very weak or no staining (Fig. 5; data not shown for 115). Furthermore, inclusions were negative for $\alpha$ Syn cleaved after residues 125 or 129 (data not shown). These findings reveal a distinct pattern of $\alpha$ Syn truncations, distinguishing AD/ALB from LBD (Fig. 3).

GCIs, distinct $\alpha$ Syn inclusions in oligodendrocytes characteristic for MSA were highly reactive with antibodies to $\alpha$ Syn truncated after residues 119,115 , and 103 in both the cerebellum and the pons (Fig. 6). GCIs were also weakly positive for a $\alpha$ Syn $x$-122 specific antibody in the cerebellum and pons, but this antibody highlighted more strongly neuronal and neuritic pathology in the pontine nuclei [25] (Fig. 6). In contrast, this neuronal pathology in the pontine nuclei was not labeled with $\alpha$ Syn $x-103$ antibodies, while it showed extensive labelling with antibody $4 \mathrm{H} 11$ specific for $\alpha$ Syn $x-119$. $\alpha$ Syn inclusion pathology in MSA was not labelled with antibodies specific for $\alpha$ Syn x-129 (data not shown) and antibodies to $\alpha$ Syn $x-125$ only revealed patchy labeling of GCIs (data not shown).

\section{Biochemical analyses reveal that aSyn $x-125$ is abundant in aggregated aSyn from LBD brain and aSyn x-125 pathology is revealed in ethanol fixed tissue.}

Biochemical fractionation of brain tissue from patients with LBD followed by immunoblotting demonstrated that detergent-insoluble, aggregated $\alpha$ Syn is only present in patients with Lewy body pathology and not in controls (Fig. 7). However, these analyses also revealed the presence of an abundant protein band that seem to correspond to $\alpha$ Syn truncated at residue 125 , which was confirmed by immunoblotting with the specific antibody $5 \mathrm{C} 1$ (Fig. 7). In fact, this truncated form of $\alpha$ Syn was only present in the detergent insoluble brain fraction. This finding was perplexing since Lewy body pathology was not labeled by $\mathrm{IHC}$ with antibodies $2 \mathrm{~B} 1$ and $5 \mathrm{C} 1$ in formalin fixed paraffin embedded tissue specimens. Given 


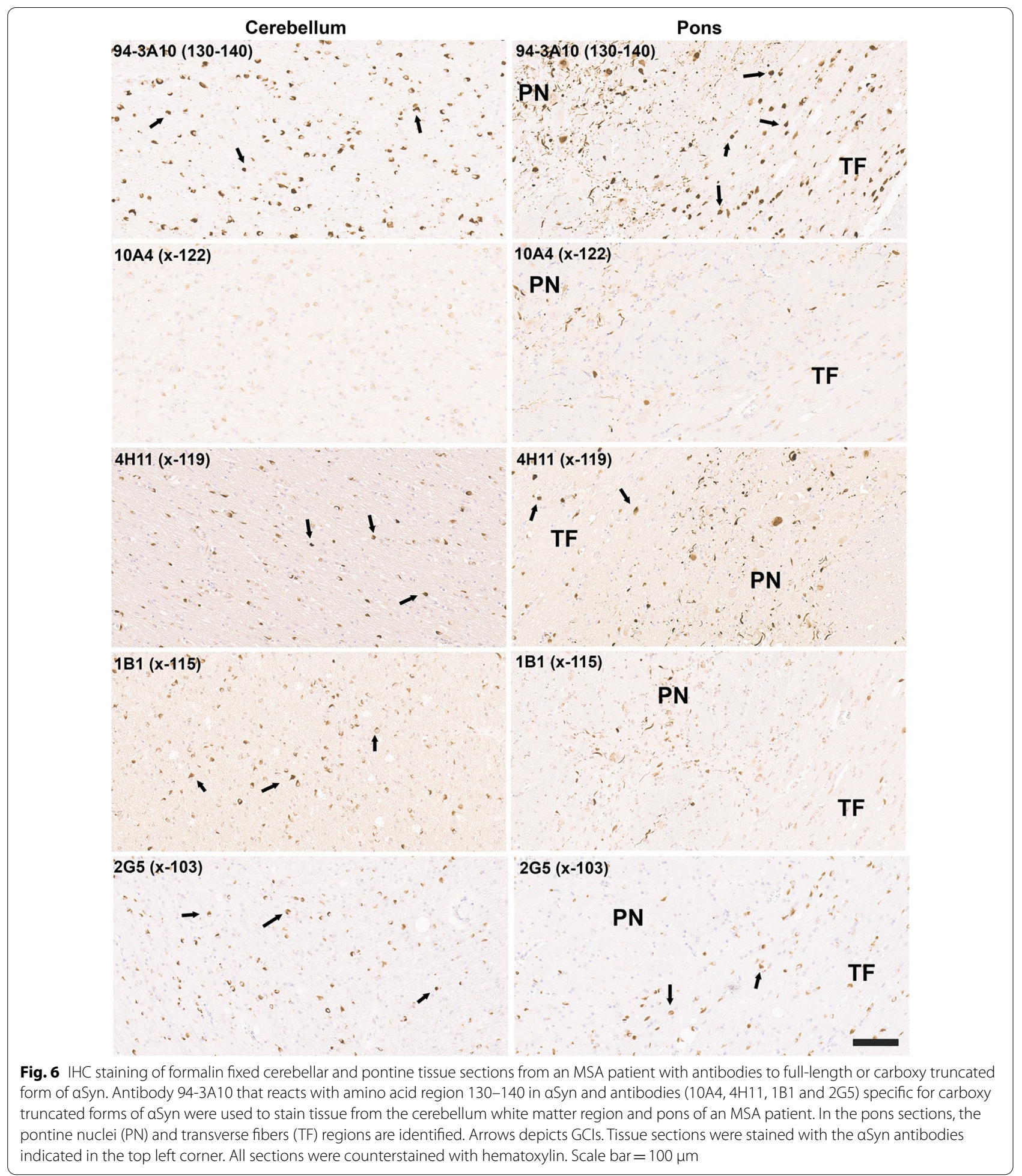

the high degree of specificity of these antibodies to carboxy truncation neo-epitopes we reasoned that they might be sensitive to formalin fixation. Therefore, a series of human postmortem specimens that were fixed in ethanol instead of formalin was obtained for IHC analysis (Table 3). In line with our previous findings (Fig. 3) in formalin fixed tissue, classical LBs in the substantia nigra of ethanol fixed tissue samples were extensively stained 

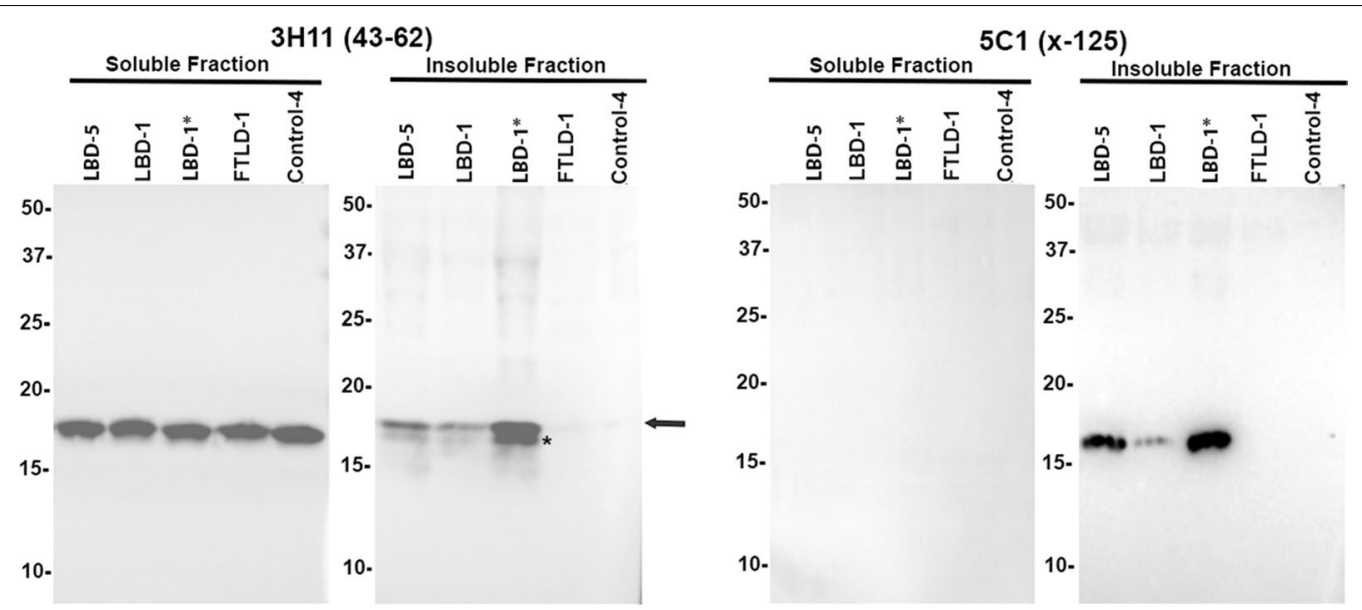

Fig. 7 Biochemical fractionation followed by immunoblotting demonstrating that aSyn carboxy truncated at residue 125 is abundant in the brain of LBD patients. LBD temporal cortex adjacent to the amygdala, LBD amygdala (*), and control temporal cortex adjacent to the amygdala were biochemically fractionated as described in "Material and Methods". 20 ug of protein from the soluble (high salt soluble) and insoluble (SDS/urea) fractions were analyzed by immunoblotting with antibody $3 \mathrm{H} 11$ with epitope in the middle of aSyn residues $43-62$ and antibody 5C1 specific for aSyn carboxy truncated at residue 125. The relative mobilities of molecular mass protein markers are identified on the left of the blots. Arrow indicates full-length aSyn and asterisk truncated aSyn

with antibodies to $\alpha$ Syn truncated after residues 122, 119, and 103, but also showed strong immunoreactivity with antibodies specific for truncation at residue 125 (Fig. 8). This type of pathology remained negative with antibodies to $\alpha$ Syn $x-115$ or $x-129$ even in ethanol fixed tissue (data not shown). Similar findings were obtained for cortical LB and Lewy neurites in ethanol fixed LBD tissue where these were now extensively labeled with antibodies to $\alpha$ Syn $x-125$ (Fig. 9). In ethanol fixed tissue from MSA patients, GCIs in the cerebellum and pons, as well as neuronal inclusions in the pons were more strongly labeled with $\alpha$ Syn $x-125$ antibodies $2 \mathrm{~B} 1$ and $5 \mathrm{C} 1$ (Figs. 10 and 11) in contrast to data obtained from formalin fixed tissue (Fig. 6).

\section{Discussion}

$\alpha$ Syn is an abundant neuronal CNS protein but the biological triggers that initiate its aggregation are still controversial. Experimentally, it is clear that the presence of preformed fibrillar $\alpha$ Syn seeds can kick-start this process and that different types of seeds have different potencies that can be propagated with altered properties akin to prion-like strains $[8,27,64]$. $\alpha$ Syn carboxy terminal truncation that can result from varied but specific biological activities is a predominant post-translational modification associated with the formation of $\alpha$ Syn pathological inclusions and this type of modification can dramatically promote the aggregation of $\alpha$ Syn, as the highly negatively charged carboxy terminal region inhibits this process when intact (reviewed in [57]). Additionally, we previously showed that these truncated forms of $\alpha$ Syn can readily form fibrils in conjunctive with full-length $\alpha$ Syn and seed pathology similarly to that of full-length $\alpha$ Syn alone $[59,60]$, which suggests that the presence of truncated $\alpha$ Syn can initiate and propagate aggregation of fulllength $\alpha$ Syn.

To provide novel insights on the disease-, regional-, and cell-specific distribution of the major types of $\alpha$ Syn carboxy truncations, a series of specific monoclonal antibodies to $\alpha$ Syn cleaved after residues $103,115,119$, 122,125 , and 129 was generated that only recognized neo-epitopes resulting from these specific truncations of $\alpha$ Syn. Using these antibodies, new and unexpected region- and disease-specific signatures were revealed (Fig. 12; Table 4). Classical Lewy body pathology and cortical-type LB and LN in the amygdalae of LBD patients were robustly labeled with the antibodies specific to $\alpha$ Syn cleaved after residues 103, 119, and 122 but negative for truncation at residues 115 and 129 . By comparison, neuronal $\alpha$ Syn inclusions in the amygdala of $\mathrm{AD} /$ ALB patients were only weakly or not labeled with antibodies for $\alpha$ Syn cleaved after residues 103, 119, or 122 . Biochemical fractionation in addition revealed $\alpha$ Syn cleaved after residues 125 as a prominent component of inclusions of LBD, which was initially not detected by 


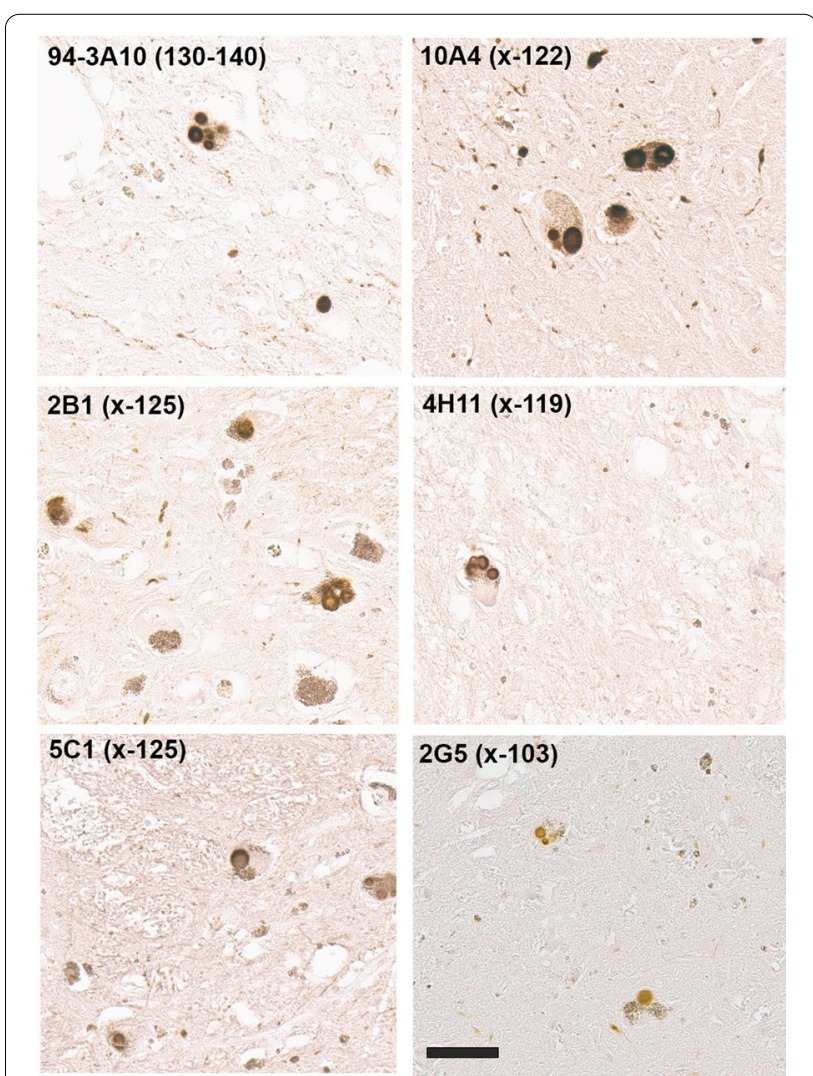

Fig. 8 IHC staining of the substantia nigra in ethanol fixed tissue sections from an LBD patient with antibodies to full-length or carboxy truncated forms of aSyn. Substantia nigra tissue sections were labeled with antibody 94-3A10 that reacts with amino acid region 130-140 in aSyn and antibodies (2B1, 5C1, 10A4, 4H11, and 2G5) specific for carboxy truncated forms of aSyn strongly labeled classic LBs. Tissue sections were stained with the aSyn antibodies indicated in the top left corner. All sections were counterstained with hematoxylin. Scale bar $=50 \mu \mathrm{m}$

immunohistochemical staining in formalin fixed tissue sections. Given the potential sensitivity of these neoepitopes to formalin fixation, we expanded our analysis to an additional set of tissues from cases fixed in ethanol. In these tissues, strong immunoreactivity of LB pathology with 125 truncation specific antibodies was observed in addition to positivity for cleavages after residues 103 , 119 , and 122 previously detected in formalin fixed tissue. This highlights the importance of tissue preservation and the combination of multiple methodologies when assessing patterns of disease specific post-translational modifications.

The stunning differences in the pattern of carboxy terminal truncations that we observed between $\alpha$ Syn inclusions in the amygdala of LBD and AD/ALB patients suggest that the biological processes involved with these diseases could be distinct. Perhaps, there are differences in the level of the proteinase activities involved in cleaving $\alpha$ Syn or the inclusions are formed by distinct mechanisms such that pathological $\alpha$ Syn in AD/ALB is not exposed to the proteinases. For example, although several non-mutually exclusive cellular mechanisms can be involved in the prion-like transmission of $\alpha$ Syn, many of these pathways involve endosomal-lysosomal compartments $[26,31,54,63,64]$. Thus, these processes can be involved in the spread of $\alpha$ Syn pathology in LBD resulting in the carboxy cleavages of $\alpha$ Syn. While in AD/ALB, it is possible that the inclusions are all formed de novo within individual cells without prion-like transmission that may account for the limited neuroanatomical location of $\alpha$ Syn pathology in AD/ALB. Alternatively, it is possible that the biological cleavage of the $\alpha$ Syn carboxy terminus is directly involved in the induction and spread of $\alpha$ Syn and that a more aggressive processing of $\alpha$ Syn in LBD directly contributes to the more ominous neuroanatomical distribution in this disease.

Braak and colleagues suggested that $\alpha$ Syn pathology in $\mathrm{PD}$ and LBD can progress via a predictable neuroanatomical distribution and that it might be initiated by some unknown factor(s) in the enteric nervous system that leads to the induction of pathology in the CNS involving specific connections such as the vagal nerve and the DMV [5-7]. Analysis of the DMV in LBD patients revealed abundant $\alpha$ Syn pathology that was intensely stained for antibodies specific for $\alpha$ Syn cleaved after residues $103,115,119$, and 122 . The additional abundant cleavage at residue 115 and the large neuroaxonal spheroids differentiated $\alpha$ Syn pathology in the DMV compared to the amygdala and substantia nigra in the same individuals. Therefore, it is possible that as proposed by Braak and colleagues, there exist some pathogens, perhaps viruses that infect the vagal system and induce the aberrant cleavage of $\alpha$ Syn, precipitating its aggregation and beginning the detrimental seeding and spread of $\alpha$ Syn pathology.

Although $\alpha$ Syn is predominantly a neuronal protein $[19,29,30,40]$, in MSA the defining pathology is abnormal aggregation of $\alpha$ Syn within oligodendrocytes as GCIs [61, 62]. GCIs were strongly reactive for $\alpha$ Syn cleaved after residues $103,115,119$, and 125 , but only displayed very weak reactivity for the 122 cleavage neoepitope. We recently reported that in the pons of MSA patients there are also abundant neuronal $\alpha$ Syn inclusions within the pontine nuclei that were more extensively revealed by a subset of antibodies with epitopes in 


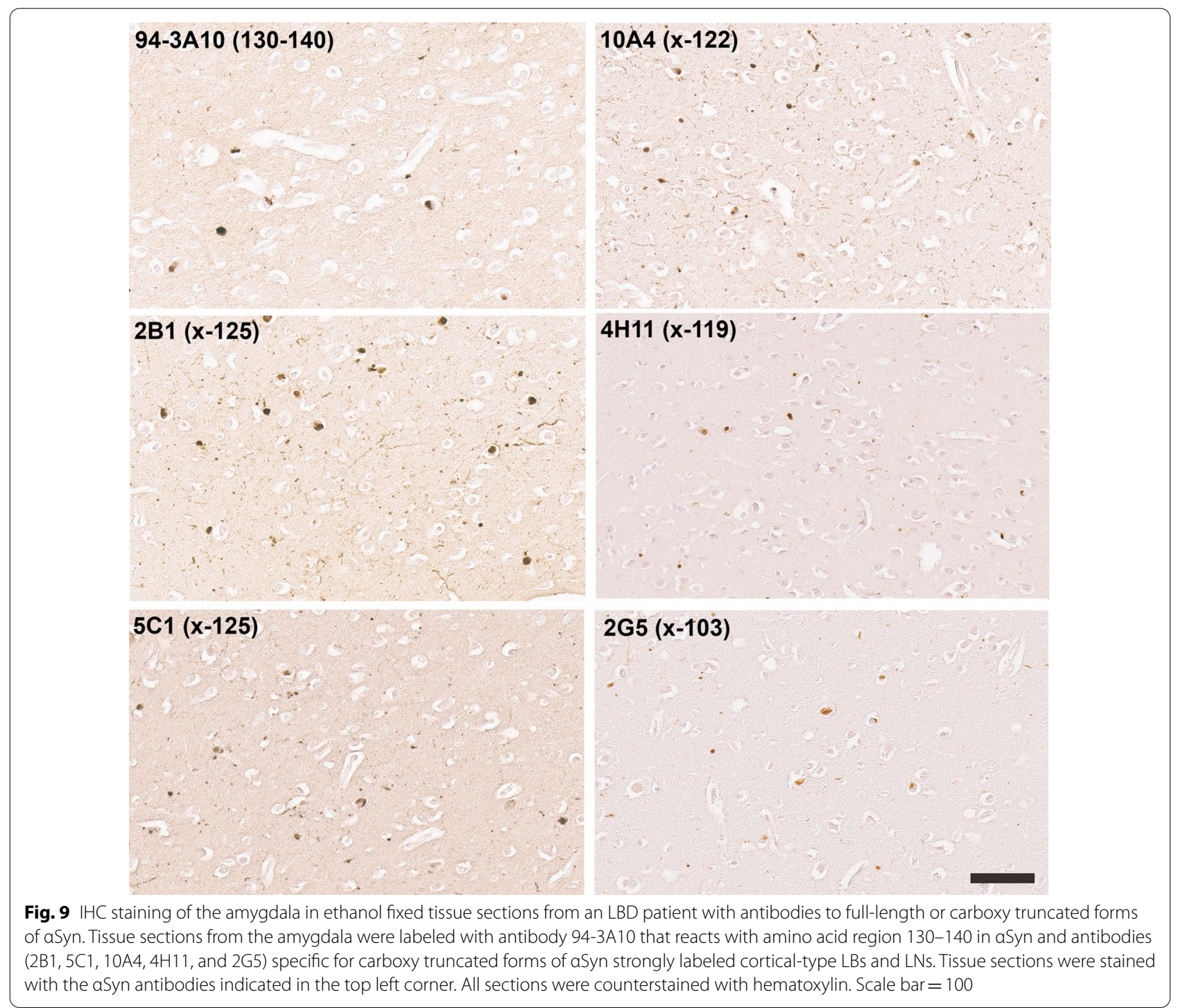

the carboxy terminus of $\alpha$ Syn [25]. This $\alpha$ Syn pathology also presents a differential profile compared to GCIs and neuronal inclusions in $\mathrm{LBD}$, as these are not reactive to $\alpha$ Syn cleaved after 103 but strongly stained for the $x-115$, $\mathrm{x}-119$, and $\mathrm{x}-122$ neo-epitope and with only modest reactivity for $x-125$. These differences might reflect relative differences in the enzyme activities responsible for these cleavages in different cellular populations, but could also be due to different prion-like conformational species with differentially present amino acid sequences available for cleavage. For example, proteinase $\mathrm{K}$ digestion is often used to assess and define the signature of different prionlike protein strains as different conformers display different accessibility to proteases. Altered cleavage profiles due to structural differences would be consistent with detailed cryo-EM analysis of MSA $\alpha$ Syn fibrils clearly demonstrating that these have different structures than those from LBD [55].

Conversely, experimental modeling studies in mice and in cultured cells implicate that the intracellular environmental milieu of the oligodendrocytes is a driving factor in producing a GCI-type $\alpha$ Syn prion strain(s) with heightened infectivity [47]. So perhaps, the protease activity profiles of oligodendrocytes is distinct from that of neurons, resulting in the differential $\alpha$ Syn cleavage products responsible for the accompanying higher pathogenicity and infectiousness of oligodendrocytic $\alpha$ Syn prion-like strain(s). This notion would be consistent 


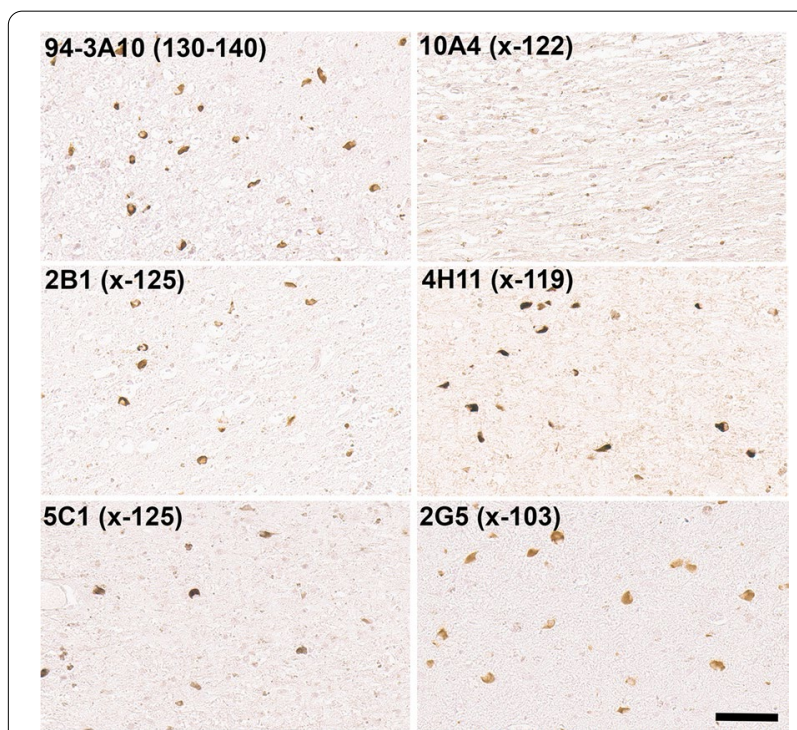

Fig. $10 \Vdash H C$ staining of the cerebellum in ethanol fixed tissue sections from an MSA patient with antibodies to full-length or carboxy truncated forms of aSyn. Cerebellar tissue sections were stained with antibody $94-3 \mathrm{~A} 10$ that reacts with amino acid region 130-140 in aSyn and antibodies (2B1, 5C1, 10A4, 4H11, and 2G5) specific for carboxy truncated forms of aSyn. Tissue sections were stained with the aSyn antibodies indicated in the top left corner. All sections were counterstained with hematoxylin. Scale bar $=60 \mu \mathrm{m}$

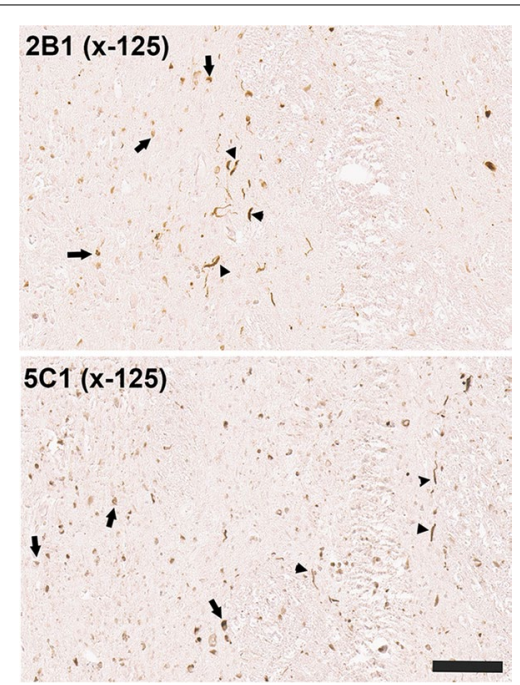

Fig. $11 \mathrm{IHC}$ staining of the pons in ethanol fixed tissue sections from an MSA patient with antibodies to aSyn carboxy truncated at residue 125 . Immuno-staining with antibodies $2 \mathrm{~B} 1$ and $5 \mathrm{C} 1$ specific for aSyn carboxy truncated at residue 125 in the pons region of an MSA patient showing reactivity for both GCls (arrow) and neuronal neuritic pathology (arrowheads). Tissue sections were stained with the aSyn antibodies indicated in the top left corner. All sections were counterstained with hematoxylin. Scale bar $=100 \mu \mathrm{m}$ with the observation that levels of $\alpha$ Syn expression are low in oligodendrocytes [43], but that pathology predominantly spreads in these cells in MSA. It is possible that $\alpha$ Syn pathology initially starts in neurons such as in the pontine nuclei where substantial pathology can be present [25] but then it is preferentially processed and propagated in oligodendrocytes despite the much lower expression levels due to a favorable cleavage environment to produce the more potent strains. Aberrant protease activities in MSA patients compared to control could exacerbate this process, and this will be investigated in future studies.

Most of the proteases involved in generating the carboxy truncated forms of $\alpha$ Syn are found in lysosomes [57]. For some cleavages, more than one protease has been implicated. For example, cathepsin L and asparagine endopeptidase can process $\alpha$ Syn between residues 103 and 104 [41, 69]. It is largely unknown if different cell types and populations in the CNS have different profiles and expression levels of the proteases implicated in cleaving $\alpha$ Syn that could account for some of the differences observed here. Nevertheless, it is interesting that many genetic risk factors associated with $\alpha$-synucleinopathies, such as glucocerebrosidase insufficiency as well as aging are likely to have impacts on these lysosomal functions and activities that can result in reduced efficiency in the degradation of $\alpha$ Syn and the aberrant accumulation of $\alpha$ Syn carboxy truncated products [4, 17, 32, 52, 67]. Given the intersection between the genetic and pathological findings suggesting a link between abnormal lysosomal activity and $\alpha$ Syn proteolytic processing, future experimental studies will directly investigate the roles carboxy truncated forms of $\alpha$ Syn as initiators and drivers of pathogenesis in the context of lysosomal alterations.

In closing, using a series of novel monoclonal antibodies to neo-epitopes resulting from specific cleavages in the carboxy terminal region of $\alpha$ Syn, we demonstrate significant and surprising disease-, region-, and celltype specific differences in the profile of $\alpha$ Syn cleavage. Future experimental studies will directly investigate the role of these truncations in the initiation and promotion of disease specific $\alpha$ Syn aggregation using in vivo models. These neo-epitopes are also prominent candidates to develop new and specific CSF and blood biomarker assays. Furthermore, since these epitopes are disease-specific, they can be used to develop future immunotherapies that would not interfere with the activity of normal $\alpha$ Syn as supported by at least one study targeting 122 carboxy truncated $\alpha$ Syn [18]. 


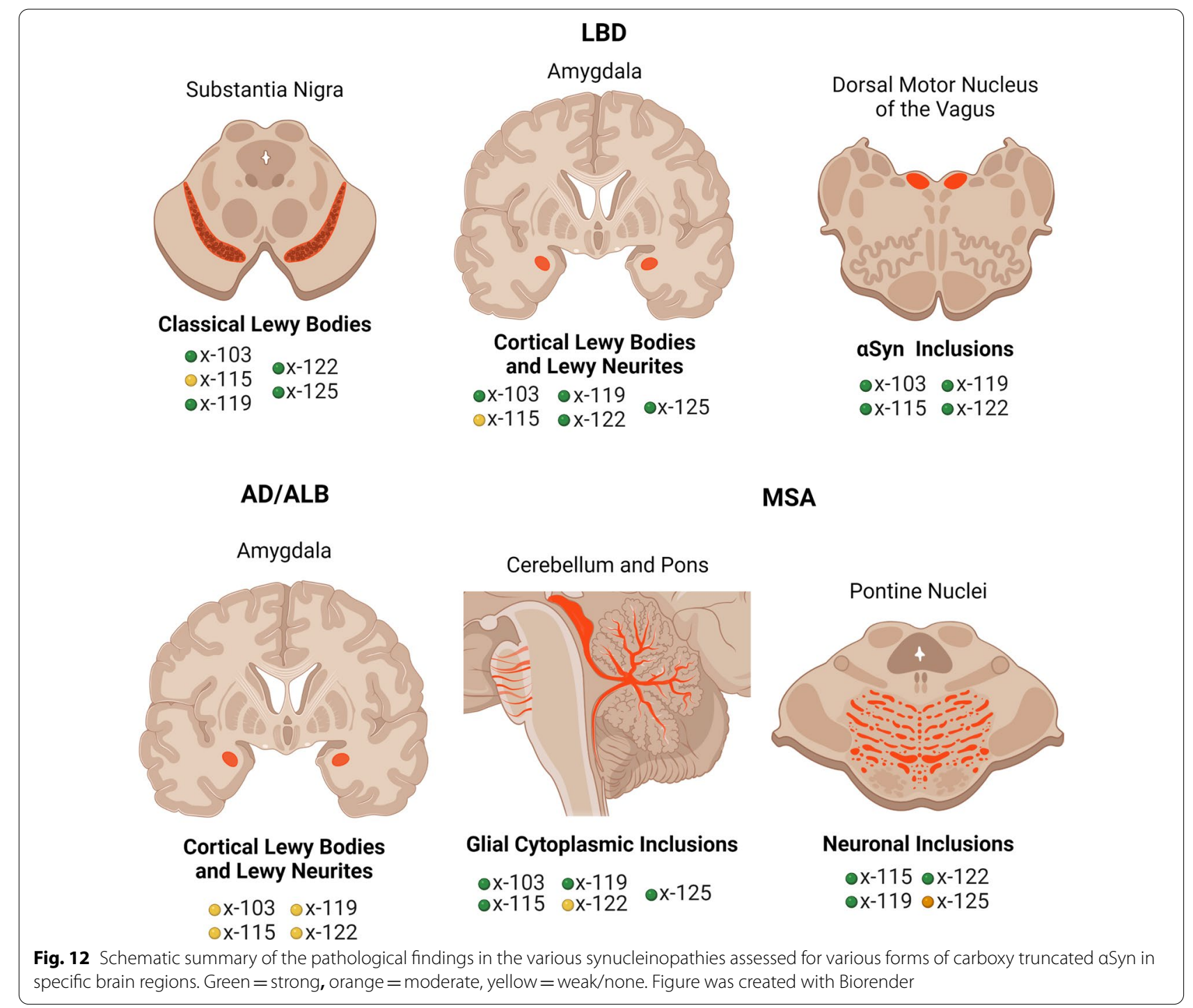

\section{Abbreviations}

AD: Alzheimer's disease; AD/ALB: Alzheimer's disease with amygdala restricted Lewy bodies; ARTAG: Aging related tau astrogliopathy; aSyn: a-synuclein; $\beta$ Syn: $\beta$-synuclein; CNDR: Center for Neurodegenerative Disease Research; DAB: 3,3'-diaminobenzidine; DLB: Dementia with Lewy body; DMV: Dorsal motor nucleus of the vagus; ELISA: Enzyme-linked immunosorbent assay; FBS: Fetal bovine serum; FTLD: Frontotemporal lobar degeneration; $\boldsymbol{\gamma S y n}$ : $\gamma$-synuclein; GCIs: Glial cytoplasmic inclusions; HS: High salt; HS/T buffer: HS buffer with 1\% Triton X-100; IHC: Immunohistochemistry; LATE: Limbic-predominant age related TDP-43 encephalopathy; LB: Lewy body; LBD: Lewy body dementia; LNs: Lewy neurites; $\mathbf{m c K L H}$ : Mariculture keyhole limpet hemocynanin; MSA: Multiple system atrophy; MSA-C: Multiple system atrophy with predominant cerebellar ataxia; MSA-P: Multiple system atrophy with predominant Parkinsonism; ND: Not determined.; PART: Primary age-related tauopathy; PBS: Phosphate buffered saline; PD Parkinson's disease; RIPA: Radioimmunoprecipitation assay; PMI: Postmortem interval; SN: Substantia nigra; TMB: 3,3'5,5'-tetramethylbenzidine; UF HBTB: University of Florida Neuromedicine Human Brain and Tissue Bank.

\section{Supplementary Information}

The online version contains supplementary material available at https://doi. org/10.1186/s40478-021-01242-2.

\section{Additional file 1:}

Additional file 1: Figure S1. ELISA characterization of the specificity of new monoclonal antibodies to carboxy truncated forms of aSyn to include $\beta S y n$ and $\gamma S y n$. ELISA were performed for all the antibodies as identified above the graphs using the specific truncated form of aSyn as well as full-length (FL) recombinant aSyn, $\beta$ Syn and $\gamma$ Syn proteins as described in "Material and Methods". $N=4$. The error bar equals standard error of the mean. 
Additional file 1: Figure S2. Immunoblotting demonstrating the specificity of aSyn carboxy truncated antibodies using soluble brain lysates. SDS-polyacrylamide gels were loaded with $10 \mathrm{ng}$ of each respective aSyn proteins as indicated above or $20 \mathrm{ug}$ of protein from the soluble (high salt soluble) fractions from the temporal cortex adjacent to the amygdala from the individuals indicated. Immunoblots were probed with the antibodies labelled above each panel.

\section{Acknowledgements}

We thank Jennifer Phillips for excellent technical assistance.

\section{Authors' contributions}

E.W.H., Z.A.S., S.P., and B.I.G. designs the experiments. E.W.H., Z.A.S., Y.X., G.M.L. and B.I.G. performed the experiments. E.W.H., Z.A.S., G.M.L., S.P. and B.I.G. analyzed the data. J.Q.T and S.P. provided clinical data and key experimental materials. E.W.H., Z.A.S., G.M.L., S.P., and B.I.G. wrote the manuscript. All authors read and approved the final manuscript.

\section{Funding}

This work was supported by grants from the National Institute on Aging (P30AG066506, P50AG047266, U19AG062418) and the National Institute of Neurological Disorders and Stroke (R01NS089022, R01NS100876, U19NS1 10456). Z.A.S. is supported by fellowship F30AG063446 from the National Institute on Aging. Y.X. is supported by fellowship F30AG067673 from the National Institute on Aging.

\section{Availability of data and materials}

All data generated or analyzed during this study are included in this published article and its supplementary information files.

\section{Declarations}

\section{Ethics approval and consent to participate}

Staining of postmortem human tissue samples was performed with approval of the University of Florida institutional review board.

\section{Consent for publication}

Informed consent was obtained according to guidelines of the University of Florida and the University of Pennsylvania institutional review board.

\section{Competing interests}

The authors declare that they have no competing interests.

\section{Author details}

'Department of Neuroscience, College of Medicine, University of Florida, BMS J483/CTRND, 1275 Center Drive, Gainesville, FL 32610, USA. ${ }^{2}$ Center for Translational Research in Neurodegenerative Disease, College of Medicine, University of Florida, Gainesville, FL 32610, USA. ${ }^{3}$ Department of Pathology and Laboratory Medicine, AD Center Core (ADCC), Center for Neurodegenerative Disease Research, PENN) School of Medicine, University of Pennsylvania, Philadelphia, PA 19104, USA. ${ }^{4}$ McKnight Brain Institute, College of Medicine, University of Florida, Gainesville, FL 32610, USA. ${ }^{5}$ Department of Pathology, College of Medicine, University of Florida, Gainesville, FL 32610, USA.

Received: 6 August 2021 Accepted: 8 August 2021

Published online: 28 August 2021

\section{References}

1. Anderson JP, Walker DE, Goldstein JM, de Laat R, Banducci K, Caccavello RJ, Barbour R, Huang J, Kling K, Lee M et al (2006) Phosphorylation of Ser-129 is the dominant pathological modification of alpha-synuclein in familial and sporadic Lewy body disease. J Biol Chem 281:29739-29752. https://doi.org/10.1074/jbc.M600933200

2. Appel-Cresswell S, Vilarino-Guell C, Encarnacion M, Sherman H, Yu I, Shah B, Weir D, Thompson C, Szu-Tu C, Trinh J et al (2013) Alpha-synuclein p.
H50Q, a novel pathogenic mutation for Parkinson's disease. Mov Disord 28:811-813. https://doi.org/10.1002/mds.25421

3. Baba M, Nakajo S, Tu PH, Tomita T, Nakaya K, Lee VM-Y, Trojanowski JQ, Iwatsubo T (1998) Aggregation of alpha-synuclein in Lewy bodies of sporadic Parkinson's disease and dementia with Lewy bodies. Am J Pathol 152:879-884

4. Bae EJ, Yang NY, Lee C, Kim S, Lee HJ, Lee SJ (2015) Haploinsufficiency of cathepsin D leads to lysosomal dysfunction and promotes cellto-cell transmission of alpha-synuclein aggregates. Cell Death Dis 6:e1901. https://doi.org/10.1038/cddis.2015.283

5. Braak H, Bohl JR, Muller CM, Rub U, de Vos RA, Del TK (2006) Stanley Fahn lecture 2005: the staging procedure for the inclusion body pathology associated with sporadic Parkinson's disease reconsidered. Mov Disord 21:2042-2051

6. Braak H, de Vos RA, Bohl J, Del TK (2006) Gastric alpha-synuclein immunoreactive inclusions in Meissner's and Auerbach's plexuses in cases staged for Parkinson's disease-related brain pathology. Neurosci Lett 396:67-72. https://doi.org/10.1016/j.neulet.2005.11.012

7. Braak H, Rub U, Gai WP, Del TK (2003) Idiopathic Parkinson's disease: possible routes by which vulnerable neuronal types may be subject to neuroinvasion by an unknown pathogen. J Neural Transm 110:517536. https://doi.org/10.1007/s00702-002-0808-2

8. Brundin P, Melki R (2017) Prying into the prion hypothesis for Parkinson's disease. J Neurosci 37:9808-9818. https://doi.org/10.1523/JNEUR OSCl.1788-16.2017

9. Campbell BC, MCLean CA, Culvenor JG, Gai WP, Blumbergs PC, Jakala P, Beyreuther K, Masters CL, Li QX (2001) The solubility of alpha-synuclein in multiple system atrophy differs from that of dementia with Lewy bodies and Parkinson's disease. J Neurochem 76:87-96

10. Chartier-Harlin MC, Kachergus J, Roumier C, Mouroux V, Douay X, Lincoln S, Levecque C, Larvor L, Andrieux J, Hulihan M et al (2004) Alpha-synuclein locus duplication as a cause of familial Parkinson's disease. Lancet 364:1167-1169

11. Cookson MR (2005) The biochemistry of Parkinson's disease. Annu Rev Biochem 74:29-52

12. Dhillon JS, Riffe C, Moore BD, Ran Y, Chakrabarty P, Golde TE, Giasson BI (2017) A novel panel of alpha-synuclein antibodies reveal distinctive staining profiles in synucleinopathies. PLoS ONE 12:e0184731. https://doi. org/10.1371/journal.pone.0184731

13. Dhillon JS, Trejo-Lopez JA, Riffe C, McFarland NR, Hiser WM, Giasson BI, Yachnis AT (2019) Dissecting alpha-synuclein inclusion pathology diversity in multiple system atrophy: implications for the prion-like transmission hypothesis. Lab Invest 99:982-992. https://doi.org/10.1038/ s41374-019-0198-9

14. Dufty BM, Warner LR, Hou ST, Jiang SX, Gomez-Isla T, Leenhouts KM, Oxford JT, Feany MB, Masliah E, Rohn TT (2007) Calpain-cleavage of alpha-synuclein: connecting proteolytic processing to disease-linked aggregation. Am J Pathol 170:1725-1738. https://doi.org/10.2353/ajpath. 2007.061232

15. Dunn SD (1986) Effects of the modification of transfer buffer composition and the renaturation of proteins in gels on the recognition of proteins on Western blots by monoclonal antibodies. Anal Biochem 157:144-153. https://doi.org/10.1016/0003-2697(86)90207-1

16. Farrer M, Kachergus J, Forno L, Lincoln S, Wang DS, Hulihan M, Maraganore D, Gwinn-Hardy K, Wszolek Z, Dickson D et al (2004) Comparison of kindreds with parkinsonism and alpha-synuclein genomic multiplications. Ann Neurol 55:174-179

17. Fernandes HJ, Hartfield EM, Christian HC, Emmanoulidou E, Zheng Y, Booth H, Bogetofte H, Lang C, Ryan BJ, Sardi SP et al (2016) ER stress and autophagic perturbations lead to elevated extracellular alpha-synuclein in GBA-N370S Parkinson's iPSC-derived dopamine neurons. Stem Cell Reports 6:342-356. https://doi.org/10.1016/j.stemcr.2016.01.013

18. Games D, Valera E, Spencer B, Rockenstein E, Mante M, Adame A, Patrick C. Ubhi K, Nuber S, Sacayon P et al (2014) Reducing C-terminal-truncated alpha-synuclein by immunotherapy attenuates neurodegeneration and propagation in Parkinson's disease-like models. J Neurosci 34:9441-9454. https://doi.org/10.1523/JNEUROSCI.5314-13.2014 
19. George JM, Jin H, Woods WS, Clayton DF (1995) Characterization of a novel protein regulated during the critical period for song learning in the zebra finch. Neuron 15:361-372

20. Gilman S, Wenning GK, Low PA, Brooks DJ, Mathias CJ, Trojanowski JQ, Wood NW, Colosimo C, Durr A, Fowler CJ et al (2008) Second consensus statement on the diagnosis of multiple system atrophy. Neurology 71:670-676. https://doi.org/10.1212/01.wnl.0000324625.00404.15

21. Goedert M (2001) Alpha-synuclein and neurodegenerative diseases. Nat Rev Neurosci 2:492-501

22. Goedert M (1997) Familial Parkinson's disease. The awakening of alphasynuclein. Nature 388:232-233

23. Goedert M, Spillantini MG, Del TK, Braak H (2013) 100 years of Lewy pathology. Nat Rev Neurol 9:13-24. https://doi.org/10.1038/nrneurol. 2012.242

24. Hamilton RL (2000) Lewy bodies in Alzheimer's disease: a neuropathological review of 145 cases using alpha-synuclein immunohistochemistry. Brain Pathol 10:378-384

25. Hass EW, Sorrentino ZA, Lloyd GM, McFarland NR, Prokop S, Giasson BI (2021) Robust alpha-synuclein pathology in select brainstem neuronal populations is a potential instigator of multiple system atrophy. Acta Neuropathol Commun 9:80. https://doi.org/10.1186/s40478-021-01173-y

26. Hijaz BA, Volpicelli-Daley LA (2020) Initiation and propagation of alphasynuclein aggregation in the nervous system. Mol Neurodegen 15:19. https://doi.org/10.1186/s13024-020-00368-6

27. Holec SAM, Woerman AL (2020) Evidence of distinct alpha-synuclein strains underlying disease heterogeneity. Acta Neuropathol. https://doi. org/10.1007/s00401-020-02163-5

28. Hyman BT, Phelps CH, Beach TG, Bigio EH, Cairns NJ, Carrillo MC, Dickson DW, Duyckaerts C, Frosch MP, Masliah E et al (2012) National Institute on Aging-Alzheimer's Association guidelines for the neuropathologic assessment of Alzheimer's disease. Alzheimers Dement 8:1-13. https://doi.org/ 10.1016/j.jalz.2011.10.007

29. Iwai A, Masliah E, Yoshimoto M, Ge N, Flanagan L, de Silva HA, Kittel A, Saitoh T (1995) The precursor protein of non-A beta component of Alzheimer's disease amyloid is a presynaptic protein of the central nervous system. Neuron 14:467-475

30. Jakes R, Spillantini MG, Goedert M (1994) Identification of two distinct synucleins from human brain. FEBS Lett 345:27-32

31. Karpowicz RJ Jr, Trojanowski JQ, Lee VM (2019) Transmission of alphasynuclein seeds in neurodegenerative disease: recent developments. Lab Invest 99:971-981. https://doi.org/10.1038/s41374-019-0195-z

32. Kaushik S, Cuervo AM (2018) The coming of age of chaperone-mediated autophagy. Nat Rev Mol Cell Biol 19:365-381. https://doi.org/10.1038/ s41580-018-0001-6

33. Kellie JF, Higgs RE, Ryder JW, Major A, Beach TG, Adler CH, Merchant K, Knierman MD (2014) Quantitative measurement of intact alpha-synuclein proteoforms from post-mortem control and Parkinson's disease brain tissue by intact protein mass spectrometry. Sci Rep 4:5797. https://doi.org/ 10.1038/srep05797

34. Kiely AP, Asi YT, Kara E, Limousin P, Ling H, Lewis P, Proukakis C, Quinn N, Lees AJ, Hardy J et al (2013) Alpha-synucleinopathy associated with G51D SNCA mutation: a link between Parkinson's disease and multiple system atrophy? Acta Neuropathol 125:753-769. https://doi.org/10.1007/ s00401-013-1096-7

35. Killinger BA, Madaj Z, Sikora JW, Rey N, Haas AJ, Vepa Y, Lindqvist D, Chen $H$, Thomas PM, Brundin P et al (2018) The vermiform appendix impacts the risk of developing Parkinson's disease. Sci Transl Med 10:eear5280. https://doi.org/10.1126/scitranslmed.aar5280

36. Kruger R, Kuhn W, Muller T, Woitalla D, Graeber M, Kosel S, Przuntek H, Epplen JT, Schols L, Riess O (1998) Ala30Pro mutation in the gene encoding alpha-synuclein in Parkinson's disease. Nat Genet 18:106-108

37. Lesage S, Anheim M, Letournel F, Bousset L, Honore A, Rozas N, Pieri L, Madiona K, Durr A, Melki R et al (2013) G51D alpha-synuclein mutation causes a novel parkinsonian-pyramidal syndrome. Ann Neurol 73:459-471. https://doi.org/10.1002/ana.23894

38. Lewis KA, Su Y, Jou O, Ritchie C, Foong C, Hynan LS, White CL 3rd, Thomas PJ, Hatanpaa KJ (2010) Abnormal neurites containing C-terminally truncated alpha-synuclein are present in Alzheimer's disease without conventional Lewy body pathology. Am J Pathol 177:3037-3050. https:// doi.org/10.2353/ajpath.2010.100552
39. Li W, West N, Colla E, Pletnikova O, Troncoso JC, Marsh L, Dawson TM, Jakala P, Hartmann T, Price DL et al (2005) Aggregation promoting C-terminal truncation of alpha-synuclein is a normal cellular process and is enhanced by the familial Parkinson's disease-linked mutations. Proc Natl Acad Sci USA 102:2162-2167. https://doi.org/10.1073/pnas.04069 76102

40. Maroteaux L, Campanelli JT, Scheller RH (1988) Synuclein: a neuronspecific protein localized to the nucleus and presynaptic nerve terminal. J Neurosci 8:2804-2815

41. McGlinchey RP, Lee JC (2015) Cysteine cathepsins are essential in lysosomal degradation of alpha-synuclein. Proc Natl Acad Sci USA 112:93229327. https://doi.org/10.1073/pnas.1500937112

42. McKeith IG, Boeve BF, Dickson DW, Halliday G, Taylor JP, Weintraub D, Aarsland D, Galvin J, Attems J, Ballard CG et al (2017) Diagnosis and management of dementia with Lewy bodies: Fourth consensus report of the DLB Consortium. Neurology 89:88-100. https://doi.org/10.1212/WNL. 0000000000004058

43. Miller DW, Johnson JM, Solano SM, Hollingsworth ZR, Standaert DG, Young AB (2005) Absence of alpha-synuclein mRNA expression in normal and multiple system atrophy oligodendroglia. J Neural Transm 112:1613-1624. https://doi.org/10.1007/s00702-005-0378-1

44. Muntane G, Ferrer I, Martinez-Vicente M (2012) alpha-synuclein phosphorylation and truncation are normal events in the adult human brain. Neuroscience 200:106-119. https://doi.org/10.1016/j.neuroscience.2011. 10.042

45. Nelson PT, Abner EL, Patel E, Anderson S, Wilcock DM, Kryscio RJ, Van Eldik LJ, Jicha GA, Gal Z, Nelson RS et al (2018) The amygdala as a locus of pathologic misfolding in neurodegenerative diseases. J Neuropathol Exp Neurol 77:2-20. https://doi.org/10.1093/jnen/nlx099

46. Pasanen P, Myllykangas L, Siitonen M, Raunio A, Kaakkola S, Lyytinen J, Tienari PJ, Poyhonen M, Paetau A (2014) Novel alpha-synuclein mutation A53E associated with atypical multiple system atrophy and Parkinson's disease-type pathology. Neurobiol Aging 35:2180-2185. https://doi.org/ 10.1016/j.neurobiolaging.2014.03.024

47. Peng C, Gathagan RJ, Covell DJ, Medellin C, Stieber A, Robinson JL, Zhang B, Pitkin RM, Olufemi MF, Luk KC et al (2018) Cellular milieu imparts distinct pathological alpha-synuclein strains in alpha-synucleinopathies. Nature 557:558-563. https://doi.org/10.1038/s41586-018-0104-4

48. Pieri L, Chafey P, Le Gall M, Clary G, Melki R, Redeker V (2016) Cellular response of human neuroblastoma cells to alpha-synuclein fibrils, the main constituent of Lewy bodies. Biochim Biophys Acta 1860:8-19. https://doi.org/10.1016/j.bbagen.2015.10.007

49. Polymeropoulos MH, Lavedan C, Leroy E, Ide SE, Dehejia A, Dutra A, Pike B, Root H, Rubenstein J, Boyer R et al (1997) Mutation in the alphasynuclein gene identified in families with Parkinson's disease. Science 276:2045-2047

50. Prasad K, Beach TG, Hedreen J, Richfield EK (2012) Critical role of truncated alpha-synuclein and aggregates in Parkinson's disease and incidental Lewy body disease. Brain Pathol 22:811-825. https://doi.org/ 10.1111/j.1750-3639.2012.00597.x

51. Proukakis C, Dudzik CG, Brier T, Mackay DS, Cooper JM, Millhauser GL, Houlden H, Schapira AH (2013) A novel alpha-synuclein missense mutation in Parkinson disease. Neurology 80:1062-1064. https://doi.org/10. 1212/WNL.0b013e31828727ba

52. Robak LA, Jansen IE, Van Rooij J, Uitterlinden AG, Kraaij R, Jankovic J, Heutink P, Shulman JM (2017) Excessive burden of lysosomal storage disorder gene variants in Parkinson's disease. Brain 140:3191-3203. https://doi.org/ 10.1093/brain/awx285

53. Rutherford NJ, Brooks M, Giasson BI (2016) Novel antibodies to phosphorylated alpha-synuclein serine 129 and NFL serine 473 demonstrate the close molecular homology of these epitopes. Acta Neuropathol Commun 4:80. https://doi.org/10.1186/s40478-016-0357-9

54. Sacino AN, Brooks MM, Chakrabarty P, Saha K, Khoshbouei H, Golde TE, Giasson BI (2017) Proteolysis of alpha-synuclein fibrils in the lysosomal pathway limits induction of inclusion pathology. J Neurochem 140:662-678. https://doi.org/10.1111/jnc.13743

55. Schweighauser M, Shi Y, Tarutani A, Kametani F, Murzin AG, Ghetti B, Matsubara T, Tomita T, Ando T, Hasegawa K et al (2020) Structures of alphasynuclein filaments from multiple system atrophy. Nature 585:464-469. https://doi.org/10.1038/s41586-020-2317-6 
56. Singleton AB, Farrer M, Johnson J, Singleton A, Hague S, Kachergus J, Hulihan M, Peuralinna T, Dutra A, Nussbaum R et al (2003) alpha-Synuclein locus triplication causes Parkinson's disease. Science 302:841

57. Sorrentino ZA, Giasson BI (2020) The emerging role of alpha-synuclein truncation in aggregation and disease. J Biol Chem 295:10224-10244. https://doi.org/10.1074/jbc.REV120.011743

58. Sorrentino ZA, Goodwin MS, Riffe CJ, Dhillon JS, Xia Y, Gorion KM, Vijayaraghavan N, McFarland KN, Golbe LI, Yachnis AT et al (2019) Unique alpha-synuclein pathology within the amygdala in Lewy body dementia: implications for disease initiation and progression. Acta Neuropathol Commun 7:142. https://doi.org/10.1186/s40478-019-0787-2

59. Sorrentino ZA, Hass E, Vijayaraghavan N, Gorion KM, Riffe CJ, Dhillon JS, Giasson BI (2020) Carboxy-terminal truncation and phosphorylation of alpha-synuclein elongates survival in a prion-like seeding mouse mode of synucleinopathy. Neurosci Lett 732:135017. https://doi.org/10.1016/j. neulet.2020.135017

60. Sorrentino ZA, Vijayaraghavan N, Gorion KM, Riffe CJ, Strang KH, Caldwell J, Giasson BI (2018) Physiological carboxy-truncation of alpha-synuclein potentiates the prion-like formation of pathological inclusions. J Biol Chem 293:18914-18932. https://doi.org/10.1074/jbc.RA118.005603

61. Spillantini MG, Crowther RA, Jakes R, Cairns NJ, Lantos PL, Goedert M (1998) Filamentous alpha-synuclein inclusions link multiple system atrophy with Parkinson's disease and dementia with Lewy bodies. Neurosci Lett 251:205-208

62. Tu PH, Galvin JE, Baba M, Giasson B, Tomita T, Leight S, Nakajo S, Iwatsubo T, Trojanowski JQ, Lee VM-Y (1998) Glial cytoplasmic inclusions in white matter oligodendrocytes of multiple system atrophy brains contain insoluble alpha-synuclein. Ann Neurol 44:415-422

63. Tyson T, Steiner JA, Brundin P (2016) Sorting out release, uptake and processing of alpha-synuclein during prion-like spread of pathology. J Neurochem 139(Suppl 1):275-289. https://doi.org/10.1111/jnc.13449
64. Uchihara T, Giasson Bl (2015) Propagation of alpha-synuclein pathology: hypotheses, discoveries, and yet unresolved questions from experimental and human brain studies. Acta Neuropathol 131:49-73. https://doi.org/ 10.1007/s00401-015-1485-1

65. Uchikado H, Lin WL, DeLucia MW, Dickson DW (2006) Alzheimer disease with amygdala Lewy bodies: a distinct form of alpha-synucleinopathy. J Neuropathol Exp Neurol 65:685-697. https://doi.org/10.1097/01.jnen. 0000225908.90052 .07

66. Waxman EA, Giasson BI (2008) Molecular mechanisms of alpha-synuclein neurodegeneration. Biochim Biophys Acta 1792:616-624

67. Wong YC, Krainc D (2016) Lysosomal trafficking defects link Parkinson's disease with Gaucher's disease. Mov Disord 31:1610-1618. https://doi. org/10.1002/mds.26802

68. Zarranz JJ, Alegre J, Gomez-Esteban JC, Lezcano E, Ros R, Ampuero I, Vidal L, Hoenicka J, Rodriguez O, Atares B et al (2004) The new mutation, E46K, of alpha-synuclein causes Parkinson and Lewy body dementia. Ann Neurol 55:164-173

69. Zhang Z, Kang SS, Liu X, Ahn EH, Zhang Z, He L, luvone PM, Duong DM, Seyfried NT, Benskey MJ et al (2017) Asparagine endopeptidase cleaves alpha-synuclein and mediates pathologic activities in Parkinson's disease. Nat Struct Mol Biol 24:632-642. https://doi.org/10.1038/nsmb.3433

\section{Publisher's Note}

Springer Nature remains neutral with regard to jurisdictional claims in published maps and institutional affiliations.
Ready to submit your research? Choose BMC and benefit from:

- fast, convenient online submission

- thorough peer review by experienced researchers in your field

- rapid publication on acceptance

- support for research data, including large and complex data types

- gold Open Access which fosters wider collaboration and increased citations

- maximum visibility for your research: over $100 \mathrm{M}$ website views per year

At BMC, research is always in progress.

Learn more biomedcentral.com/submissions 